\title{
Bronchial asthma and COPD due to irritants in the workplace - an evidence-based approach
}

\author{
Xaver Baur*, Prudence Bakehe and Henning Vellguth
}

\begin{abstract}
Background: Respiratory irritants represent a major cause of occupational obstructive airway diseases. We provide an overview of the evidence related to irritative agents causing occupational asthma or occupational COPD.

Methods: We searched MEDLINE via PubMed. Reference lists of relevant reviews were also screened. The SIGN grading system was used to rate the quality of each study. The modified RCGP three-star system was used to grade the body of evidence for each irritant agent regarding its causative role in either occupational asthma or occupational COPD.

Results: A total of 474 relevant papers were identified, covering 188 individual agents, professions or work-sites. The focus of most of the studies and the predominant diagnosis was occupational asthma, whereas occupational COPD arose only incidentally.

The highest level assigned using the SIGN grading was 2+ (well-conducted systematic review, cohort or case-control study with a low risk of confounding or bias). According to the modified RCGP three-star grading, the strongest evidence of association with an individual agent, profession or work-site ("**") was found for 17 agents or work-sites, including benzene-1,2,4-tricarboxylicacid-1,2-anhydride, chlorine, platinum salt, isocyanates, cement dust, grain dust, animal farming, environmental tobacco smoke, welding fumes or construction work. Phthalic anhydride, glutaraldehyde, sulphur dioxide, cotton dust, cleaning agents, potrooms, farming (various), foundries were found to be moderately associated with occupational asthma or occupational COPD ("* $[+]^{\prime \prime)}$.
\end{abstract}

Conclusion: This study let us assume that irritant-induced occupational asthma and especially occupational COPD are considerably underreported. Defining the evidence of the many additional occupational irritants for causing airway disorders will be the subject of continued studies with implications for diagnostics and preventive measures.

Keywords: Work-related asthma, Occupational asthma, Occupational COPD, RADS, Irritant-induced asthma

\section{Introduction}

Bronchial asthma and chronic obstructive pulmonary disease (COPD) are common conditions and are the dominating obstructive airway diseases in the general population.

\section{Work-related asthma (WRA) including irritant-induced occupational asthma (OA)}

Occupational asthma is defined as a chronic inflammatory disorder of the airways with recurrent episodes of coughing, wheezing, chest tightness, dyspnea, shortness

\footnotetext{
* Correspondence: baur@uke.uni-hamburg.de

Institute for Occupational and Maritime Medicine, University Medical Center Hamburg-Eppendorf, Seewartenstr. 10, 20459, Hamburg, Germany
}

of breath at rest, and reversible airflow limitations caused by a particular occupational environment [1-3].

The available epidemiological and comparative studies and reviews provide evidence that occupational agents cause $5-25 \%$ of all asthma cases [1,4-23]. Besides these evident occupational asthma (OA) cases, there is probably an even larger population of sufferers of workaggravated asthma [24-26]. The latter population shows an objective worsening of pre-existing asthma or nonoccupational asthma that develops in parallel with causative conditions encountered in the workplace (Figure 1).

Occupational agents eliciting bronchial asthma, i.e. OA, comprise occupational allergens, with their well-defined etiological role and IgE-mediated pathomechanism, as

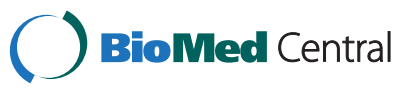




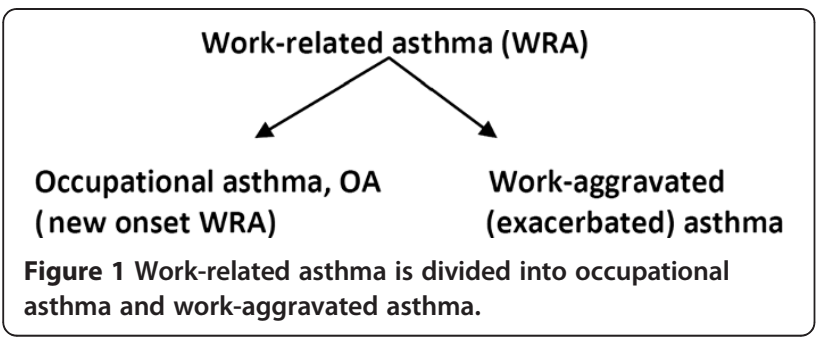

well as occupational agents with unknown pathomechanisms and occupational respiratory irritants, mainly representing low molecular weight chemicals (LMW; $<5000$ Daltons) causing irritant-induced OA (Figure 2). The latter agents may also elicit occupational COPD (see chapter 1.2) and include chlorine, acids, welding fumes, as well as isocyanates. The etiological role of such low molecular chemicals has not yet been completely clarified, primarily because of the lack of specific diagnostic tests.

There is sparse data available on causes and frequencies of irritant-induced COPD and work-aggravated asthma. Therefore, this work focuses on irritant-induced OA.

There is increasing evidence that irritant-induced OA can be further subdivided into three subcategories as outlined in Table 1 [27-29].

Many case reports, case series and a few crosssectional studies demonstrate that a single short-term accidental massive exposure or several short-term highlevel exposures to a respiratory irritant can cause asthma within 24 hours without a latency period. Brooks et al. [30] defined this disorder as "reactive airways dysfunction syndrome" (RADS). This term was later extended to irritant-induced OA from multiple, somewhat lower, exposure incidents with a less sudden onset that were also shown to cause this disorder [27,31-36].

\section{Occupational asthma (OA) (new onset WRA)

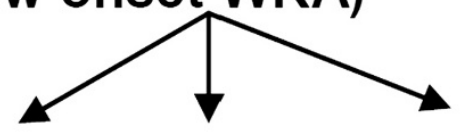 \\ $\lg \mathrm{E}$ media- ted OA \\ OA \\ due to specific occupational agents with unknown patho- mechanism}

Figure 2 Subgroups of $O A$.
Table 1 Subcategories of irritant-induced OA

\begin{tabular}{lll}
\hline $\begin{array}{l}\text { Subcategories of } \\
\text { irritant-induced OA }\end{array}$ & $\begin{array}{l}\text { Exposure } \\
\text { concentration }\end{array}$ & $\begin{array}{l}\text { Duration of } \\
\text { exposure }\end{array}$ \\
\hline $\begin{array}{l}\text { Reactive airways dysfunction } \\
\text { syndrome (RADS) }\end{array}$ & $\begin{array}{l}\text { Extremely high, }>\text { OEL } \\
\leq 1 \text { day }\end{array}$ \\
\hline $\begin{array}{l}\text { Not so sudden onset of } \\
\text { irritant-induced OA }\end{array}$ & Moderate, around OEL & $>1$ day $<4$ months \\
\hline $\begin{array}{l}\text { Low dose irritant- } \\
\text { induced OA }\end{array}$ & Low, below OEL & $>4$ months \\
\hline
\end{tabular}

$\mathrm{OA}=$ Occupational asthma, $\mathrm{OEL}=$ Occupational Exposure Limit.

Furthermore, there is evidence that a susceptible subgroup of subjects mainly atopics with non-specific bronchial hyperresponsiveness (NSBHR) suffering from irritant-induced OA, is also affected by chronic exposures to relatively low concentrations of irritant gases, fumes or aerosols $[27,37,38]$. This disorder has been called "low-dose irritant asthma" (or "low-dose RADS"). Corresponding studies indicate respiratory effects including asthma from mainly chronic or repeated exposure to a single irritant or a mixture. Demonstrably causative concentrations of a particular irritant are often below their occupational exposure limits (OELs) or permissible exposure limits (PELs). Such irritant examples include swine confinement facilities [39,40], exposures to cleaning agents $[12,41]$, solvents, ozone, endotoxin, formaldehyde, quaternary ammonium compounds, chlorine, bisulfite and $\mathrm{SO}_{2}$, or acid mist $[36,37,42-44]$, diesel exhaust $[10,45,46]$, fumigant residues [47], dusts in the textile paper, mineral fiber or construction industries or in mines [48-51], as well as a proportion of cases of potroom asthma [52] and meatwrappers' asthma [53]. Asthma in cold-air athletes may also be relevant $[54,55]$. A previous summary of the literature on respiratory effects from asthma due to irritants below their OELs/PELs is available [56]. Many of the earlier exposure limits have been lowered repeatedly in the light of subsequent clinical or epidemiological findings on their respiratory effects. Other limits remain obstinately high given their known irritative effects and/ or that they are based on sparse data [56]. Accordingly, adherence to OELs/PELs does not preclude the onset of WRA in susceptible subjects.

The broader definition of these disorders (as used in the legal definition in Germany) includes all irritantinduced obstructive airway diseases irrespective of their causative concentrations and reversibility, i.e. irritantinduced occupational asthma as well as COPD.

\section{Frequency of $\mathrm{OA}$}

OA has become the most prevalent occupational lung disease in developed countries [57,58] and it is one of the most frequent diagnosis among occupational diseases in general [59]. The annual incidence of OA is in 
the range of 50 per million with extremes up to 250 per million workers and more than 1,300 per million in specific workplaces $[57,60]$. As already mentioned there is evidence that occupational agents cause $5-25 \%$ of of all asthma cases. However, complete registries of OA do not exist and therefore the true frequency of the disease is unknown. Ameille et al. [61] and Fernández-Nieto et al. [59] stated that OA is underestimated among occupational diseases, because many OA cases are not subjected to appropriate diagnostic tests.

Irritant-induced OA is reported to occur in approximately $5-18 \%$ of all OA cases, being the second most common form of OA after allergic OA $[36,62]$.

\section{Chronic obstructive pulmonary disease (COPD) due to occupational exposure}

The diagnosis of COPD is based on chronic productive cough, airflow limitation that is usually not fully reversible, and a progressive, abnormal inflammative response of the lungs mostly caused by long-term smoking and by other noxious particles or gases [1].

During ongoing causative exposures (e.g. smoking particles, droplets and/or gases), airflow limitation is usually progressive and associated with an abnormal inflammatory response of the lungs. Patients with COPD have greater number of neutrophils and alveolar macrophages in bronchoalveolar lavage fluid than healthy nonsmokers [63]. Sites of emphysema, which are frequently found in COPD patients, contain large numbers of lymphocytes, and the extent of lymphocyte accumulation correlates with reduction of $\mathrm{FEV}_{1}$.

In their summaries of the literature, Hnizdo et al. [64], Trupin et al. [65] and Balmes et al. [1] found an occupational contribution in about 15\% of COPD cases.

Occupational COPD is identified on epidemiological basis, by observing increased frequencies of COPD among certain working groups [66], e.g. in construction workers [2]. Some occupational exposures (e.g. welding fumes, aluminium, potroom fumes, and cadmium) may cause COPD associated with emphysema $[67,68]$.

At later stages of $\mathrm{OA}$, the condition of some subjects does not improve over weekends or during holidays and coincides with symptoms of COPD patients. This observation also applies to non-occupational obstructive airways diseases [69,70] and indicates that a group with changing diagnoses as well as with some overlap between $\mathrm{OA}$ and occupational COPD, does exist [66,71-73].

\section{Background and objective}

WRA and occupational COPD are serious and sometimes fatal diseases, which can lead to ill health, inability to work and lost productivity [1,25,74-76]. They represent a huge economic burden to the society. For details see Additional file 1: Online Supplement "Economic burden".

The objective of this study is to summarize present knowledge on respiratory irritants causing obstructive airway diseases in humans in the occupational setting and to provide a rating of the strength of evidence for each irritant which has not been previously available.

\section{Methodology}

A systematic review of the literature on occupational irritant-induced OA and occupational COPD due to occupational irritants was conducted. We considered asthma-inducing irritating agents as well as those reported to cause occupational COPD and related disorders, where obstructive ventilation patterns were demonstrated in clinical investigations, cross-sectional studies, cross-shift and/or in long-term exposure studies. Irritating gases mainly occurring in the general environment, such as ozone, and inorganic dusts, including silica, talcum, silicates and other fibers known to cause pneumoconioses, were not considered even though exposure to them is frequently associated with mixed ventilation patterns.

\section{Definitions used}

Occupational COPD: chronic bronchitis symptoms and non-reversible airflow limitation due to particular occupational environment (if lung function data was available; otherwise, clinical diagnosis as given by the authors is cited).

Occupational asthma: episodes of shorteness of breath due to particular occupational environment and reversible airflow limitation (if lung function data was available; otherwise, clinical diagnosis as given by the authors is cited).

Obstructive ventilation pattern: we applied reference values of $\mathrm{FEV}_{1} / \mathrm{FVC}$ from Brändli, Schindler et al. 2000 [77].

\section{Information sources and selection criteria Occupational respiratory irritants}

To identify the evidence of irritants of the respiratory tract, all agents denoted as "may cause respiratory irritation" by the phrase H335 (previous code R37) and "may cause allergy or asthma symptoms or breathing difficulties if inhaled" H334 (previous code R42) [78] and/or as "irritants" by American Conference of Governmental Industrial Hygienists [79] were initially listed [80]; later this list was compared with results of our database search (see below).

Database search.

We searched for publications reporting investigations exclusively in humans (i.e. animal or in-vitro research was excluded). To be included, the publications had to 
deal with subjects occupationally exposed to airway irritants.

MEDLINE ${ }^{\circledR}$-Database was searched with PubMed $^{\circledR}$ from its inception up to December 2007 with the following medical subject headings $(\mathrm{MeSH})$ combinations for each single agent:

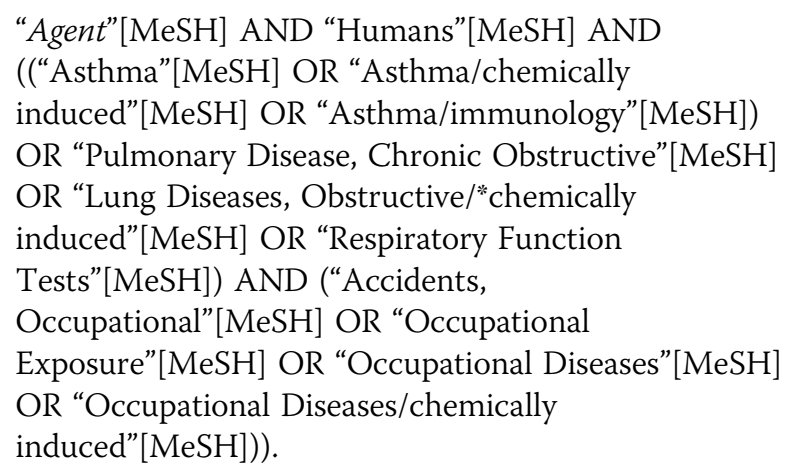

If more than 20 publications per agent were found, the search was more specified:

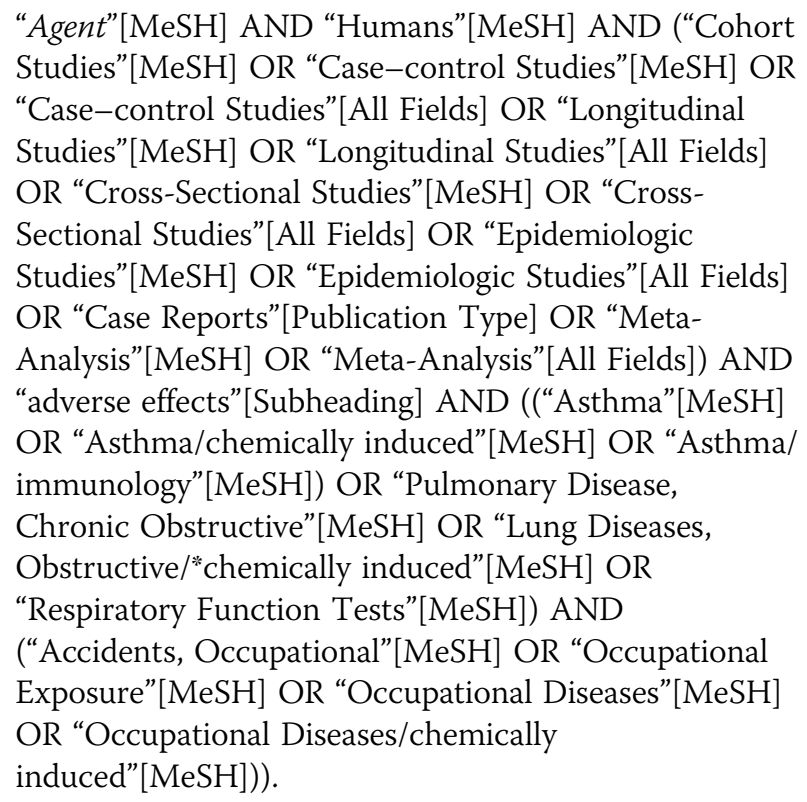

\section{Reference list screening}

We also considered references in the identified already existing 13 systematic reviews or overviews of causes of work-related asthma or COPD and tried to combine results of both approaches.

\section{Occupational diseases statistics}

Further, we considered the following occupational diseases statistics based either on statutory surveillance or registration systems: SWORD 1994-1997 [81-83]; SHIELD 1993 [74]; SORDSA 2001 [84]; SENSOR 2003
[85]; Dokumentation der Berufskrankheiten 2007 (BKDOK) [86].

\section{Conditions}

Four different conditions were accepted for inclusion:

1. Irritant-induced OA including RADS. Asthma caused by single or multiple occupational exposures to airway irritants; de novo irritant-induced OA. Asthma within 24 hours without a latency period caused by short-term high-level exposures to a respiratory irritant known as acute irritant-induced asthma, or as RADS [30].

2. Work-aggravated (exacerbated) irritant-induced OA. Pre-existing or concurrent asthma worsened by work factors [24]. Subjects with work-related asthmatic symptoms, if not differentiated whether new-onset or work-aggravated.

3. Occupational COPD. On epidemiological basis, identified by observing increased frequencies of COPD among certain working groups [66].

4. Obstructive ventilation pattern. Studies about irritant agents, where obstructive ventilation patterns in occupational settings were reported.

\section{Methodological selection criteria}

Publications with one of the following study designs were included: Systematic reviews of cohorts, case-control or cross-sectional studies, cohort studies (prospective/retrospective), case-control studies, cross-sectional studies, surveys.

Non-analytic $1^{\text {a }}$ studies (i.e. case series, follow-up of cases or case reports) were only included when for an agent no studies with one of the above mentioned designs had been identified.

Publications were included when they met any of the following criteria: examining the frequency of irritantinduced OA or asthmatic work-related symptoms in occupationally exposed groups or individuals, reporting the causative role of the specific agent or mixture of agents for irritant-inducing WRA or COPD.

Studies were included when they applied any of the following diagnostic tools: description of work-related asthmatic symptoms (questionnaire), lung function test (LFT), testing for non-specific bronchial hyperresponsiveness (NSBHR) by means of methacholine, histamine or other pharmacological agents, serial spirometry or expiratory peak flow (PEF) monitoring or supervised exposure testing in the workplace, challenge with the help of lung function measurements (SFT), specific inhalation challenge testing (SIC), clinical diagnosis of OA by an expert (occupational or pulmonary physician), and exposure to an irritant agent. 
Publication period: No restriction for publication dates were made, last updates were between $5^{\text {th }}$ and $15^{\text {th }}$ June 2012.

Language: English, German, Spanish, Italian or French. Methodological studies, e.g. on effects of study design and subsequent procedures, and studies with nonoccupational disorders were excluded. Publications about occupational agents which do not have an irritant effect on the respiratory tract (e.g. about IgE-sensitizing agents) or with unrelated issues (e.g. studies on immunological questions) were also excluded.

\section{Assessment of study quality}

The principal study characteristics and study results were systematically extracted using an extraction sheet (see Additional file 2: Table S1A of online supplement "Methodology").

We assessed study quality with the help of a check list (see Additional file 2: Table S1B of online supplement "Methodology"). The evidence level of each study was graded according to the revised Scottish Intercollegiate Guidelines Network (SIGN) grading system [87]. Since population-based randomized assignment to different levels of irritant exposure are unethical, no randomised controlled trials (RCTs) could be expected on this topic and, thus, no level 1 evidence (as defined by the revised SIGN grading system) [87] would be available. In order to achieve more differentiation among lower evidence grades, we modified the SIGN grading system and added an additional grade (3+) (see Additional file 2: Table S1C of online supplement "Methodology").

Details of the modified RCGP [88] grading system are given in the online supplement "Methodology", Additional file 2: Table S1D.

\section{Results}

\section{Overview on publications retrieved}

The database search (MEDLINE/ PubMed) yielded 383 potentially relevant publications. 480 additional potentially relevant publications were retrieved from the reference lists of 13 systematic reviews or overviews [2,30,36,80,89-97], from occupational diseases routine statistics (SWORD 1994-1997 [47,81-83]; SHIELD 1993 [74]; SORDSA 2001 [84]; SENSOR 2003 [85]; BK-DOK 2007 [86], and from the library of the Institute of Occupational Medicine, Hamburg. Alltogether, the different search approaches yielded a total of 474 relevant studies, including an extreme early study from the year 1932 [98]. (See selection flow diagram, Figure 3).

Most $(n=337)$ of the 474 relevant publications were identified through hand searching (i.e. reference list checking of systematic reviews and from our library database).
The 474 publications refer to 131 individual agents, 46 to "mixed" agents and 11 to work-sites or professions reported to cause OA and/ or occupational COPD.

\section{Diagnostic aspects}

Many different ways of confirming irritant-induced OA were used, with specific inhalation challenge (SIC) and lung function tests (LFT) being the most reliable diagnostic aids.

SIC was used as the "gold standard" in confirming OA mainly in non-analytical studies $(n=189$ studies, i.e. $72 \%$ of non-analytical studies). Only few $(n=16$, i.e. $7.5 \%$ of analytical studies) cohort or case-control reported diagnostic confirmation with SIC.

Another frequently used $(n=191)$ diagnostic method for OA or occupational COPD was lung function testing (LFT); showing an obstructive ventilation pattern and/or NSBHR related to occupational exposures, mostly in combination with WRA symptoms.

Exclusively self-reported asthma symptoms or physician reported asthma as documented in questionnaires as an alternative diagnosis for OA was used in 36 studies.

Other studies $(n=44)$ had not clear diagnosis of OA or occupational COPD but reported obstructive ventilation pattern. The number of subjects with asthma symptoms and frequencies of obstructive ventilation patterns and/or NSBHR are provided for each study (see Additional file 3: Table S2E of online supplement "Results").

\section{Irritant-induced $\mathrm{OA}$ as outcome}

Irritant-induced OA was the focus of most studies and was the predominant diagnosis.

RADS, as a subgroup of irritant-induced OA, was reported to be due to 47 different agents, with the most prevalent being the World Trade Center disaster in 2001 ( $\mathrm{n}=7$ studies), chlorine $(\mathrm{n}=11)$, cleaning agents $(\mathrm{n}=18)$ and isocyanates $(n=46)$. These were followed by disorders, caused by metam sodium $(n=17)$, ammonia $(n=11)$, diesel exhaust $(n=10)$, acids $(n=9)$, solvents $(\mathrm{n}=8)$, sulfur dioxide $(\mathrm{n}=7)$, dinitrogen tetraoxide $(n=6)$, hydrogen chloride $(n=4)$, smoke (fires, pyrolysis products $\quad(n=4)$, chlorofluorocarbons $(n=4)$, spray paint $(n=3)$, tear gas $(n=3)$, bromine $(n=2)$, dichlorvos $(n=2)$, sodium azide $(n=2)$, acrylates $(n=1)$, amprolium hydrochloride $(n=1)$, phthalic anhydride $(n=1)$, bromochlorodifluoromethane $(\mathrm{n}=1)$, bromotrifluoromethane $(\mathrm{n}=1)$, chloramine $\mathrm{T}(\mathrm{n}=1)$, chromate $(\mathrm{n}=1)$, hydrazine $(\mathrm{n}=1)$, hydrogen fluoride $(\mathrm{n}=1)$, methylmercaptan $(n=1)$, phosgene $(n=1)$, uranium hexafluoride $(n=1)$, airbag content $(n=1)$, bleaching agent $(n=1)$, floor sealant $(n=1)$, fumigant $(n=1)$, metal coat remover $(n=1)$, 


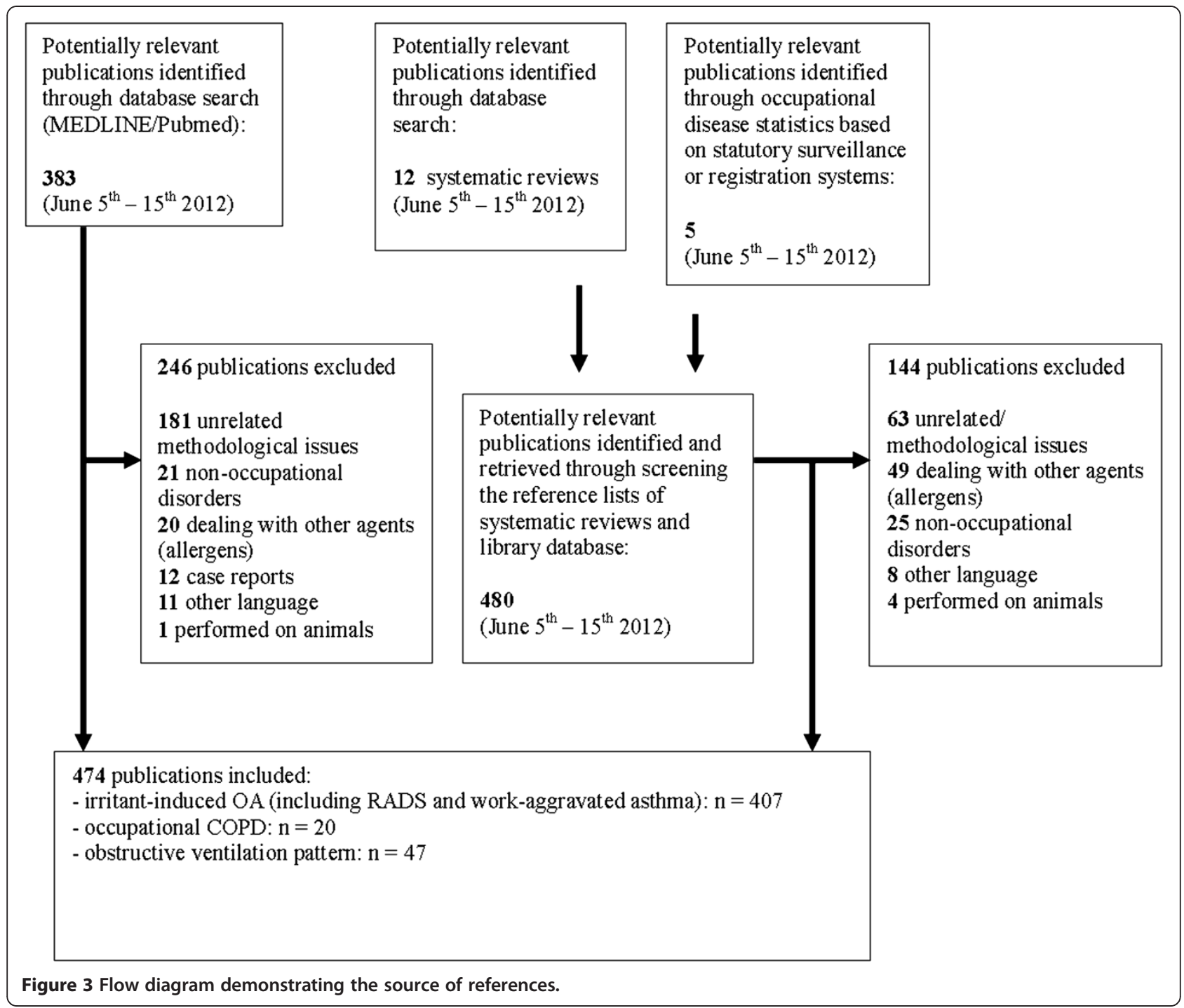

metal oxide fume $(n=1)$, pesticides $(n=1)$, refractory ceramic fibers $(n=1)$, swine confinement $(n=1)$.

The majority of asthma-inducing agents elicited OA after prolonged exposure and rarely after a single exposure.

Work-aggravated asthma was of less importance in the literature and occurred in only a few studies [30,99-104].

\section{Occupational COPD as outcome}

Ten agents and five professions or work-sites were reported to cause occupational COPD, as shown in Table 2.

As already mentioned, occupational COPD was not specifically addressed in most of the studies. Some describe respiratory symptoms, such as chronic bronchitis $(n=21)$, which may be indicative of COPD. One of the few studies which specifically focused on COPD, was a large retrospective cohort study on diesel exhaust which caused a significantly increased COPD mortality in railroad workers after the introduction of diesel engines in $1945[105,106]$. Construction work was identified as a cause of occupational COPD in 2 publications $[8,107]$.

Table 2 Agents and professions showing evidence of occupational COPD

\begin{tabular}{ll}
\hline $\begin{array}{l}\text { Agents, number } \\
\text { of studies }(\mathbf{n})\end{array}$ & $\begin{array}{l}\text { Work-sites or professions, } \\
\text { number of studies }(\mathbf{n})\end{array}$ \\
\hline o ammonia (1) & o construction work (3) \\
$\circ$ cement dust (4) & o swine confinement (1) \\
o chlorine (1) & $\circ$ farming (1) \\
o cleaning agent (1) & $\circ$ foundry (1) \\
o mustard gas (1) & $\circ$ metallurgical industry workers (1) \\
o diesel exhaust (2) & \\
o environmental tobacco smoke(1) & \\
o isocyanate (1) & \\
$\circ$ smoke (1) & \\
o sulphur dioxide (1) & \\
\hline
\end{tabular}

$\mathrm{COPD}=$ Chronic obstructive pulmonary disease. 


\section{Evidence level of the literature}

Some publications investigated more than one irritant agent and thus have been considered several times in our study.

262 of the 474 publications were non-analytic studies and were rated according to SIGN as 4,3 or $3+$ and consisted of case reports $(n=228)$, case series $(n=63)$, and occupational diseases statistics $(n=33)$ and reviews of that kind of studies $(n=7)$. The other publications reported analytical studies and were rated according to SIGN as $2+(n=15), 2-(n=103)$, or $3+(n=83)$.

The highest level was $2+$, indicating a well conducted analytical study (case control or cohort studies) with a low risk of confounding or bias ( $\mathrm{n}=15$ studies). Other studies with a similar design had a higher risk of confounding or bias and were individually rated lower by SIGN grading of 2- $(n=30$ studies). Most of the other analytical studies were rated with a SIGN grade of 2-, because their design (cross-sectional or longitudinal study) was limiting ( $\mathrm{n}=82$ studies). Cross-sectional studies or longitudinal studies, e.g. those with high risk of confounding or bias, were rated even lower with $3 / 3+$ ( $\mathrm{n}=35$ studies). A couple of study designs were difficult to classify epidemiologically, including those which were surveys, mostly with very low analytical evidence, rated $3 / 3+(n=53$ studies $)$, or larger surveys with a lower risk of confounding or bias, which were graded with 2 - $(n=4$ studies).

Investigations involving dose-response relationship as a form of scientific evidence were performed in 30 out of 474 studies analyzed [68,105,106,108-133].

Another assessment of the level of evidence found in individual studies is to consider their OR for irritant-induced OA or occupational COPD; this was done in 39 publications [15,23,44,48,105-108,113,117$120,122,126,128,134-156]$.

\section{Strength of evidence per agent, work-site or profession}

The outcome for each agent causing OA or occupational COPD was graded according to the modified RCGP three-star system to classify the strength of evidence of its causative role in irritant-induced OA/ occupational COPD. The strongest evidence achieved was two stars “\%:” (indicating a moderate strength of evidence provided by generally consistent findings in fewer, smaller or lower quality scientific studies) for 17 (mixed) agents, work-sites or professions. For six of them (chlorine, platinum salts, environmental tobacco smoke, welding fumes, construction work, World Trade Center disaster in 2001), this level was based on well- conducted studies with low risk of confounding and/or bias (SIGN 2+). For eleven of these 17 (mixed) agents, SIGN levels of individual studies were lower (benzene-1, 2, 4tricarboxylic acid-1,2-anhydride [trimellitic anhydride], cobalt, isocyanates, cement dust, grain dust, animal farming (pig, beef/veal, dairy, poultry), or swine confinement.

Low to moderate scientific evidence - provided by generally consistent findings in fewer, smaller or lower quality analytical studies, based on questionnaires or other inadequacies, i.e. “*[" $\left.{ }^{*}\right]$ " - was found for 12 agents (phthalic anhydride, glutaraldehyde [glutaral], sulfur dioxide, cotton (dust, raw) CNT 750, potroom aluminum smelting, farming (various) or foundry), smoke (fires, pyrolysis products), pesticides (not specified), cleaning agents (not specified), ceramic production (dust), health care workers.

Limited or contradictory evidence - provided by only one analytical study or inconsistent findings in multiple scientific studies, i.e.“*” - was identified for 39 agents, and after down-grading because of inadequate methodological aspects, i.e. "["*]" on three occasions. For the majority of agents, only non-analytical studies were reported for $\geq 5$ cases, i.e. " $(*)$ " or less than 5 cases, i.e. "-". When only non-analytical studies were available, the strength of evidence for the agent was raised if at least 5 cases were identified by the case reports/ case series or occupational disease statistics for which proof of irritant-induced OA or occupational COPD existed. The strength of evidence reached when only non-analytical studies were available ranged from "very limited or contradictory evidence" in 29 studies, i.e. " $\left(^{*}\right)$ ", to "no scientific evidence" "-" 94 times. (see Tables 3 and 4 and Additional file 3: Table S2E of online supplement "Result").

The compiled assessment of the individual studies, along with their relevant clinical data and strength of evidence for irritant agents, professions or workplaces causing asthma or COPD, is presented as a summary list (see Additional file 3: Table S2E "Results" for the full information).

\section{Discussion}

The main objective of this study was to give a comprehensive and evidence-based overview of the literature on irritative agents, professions or work-sites causing irritant-induced work-related asthma and occupational COPD. To our knowledge this study is the first attempts to document these respiratory disorders, along with their causative irritant agents in an evidence-based manner.

The 474 publications retrieved (see Table 3 and Additional file 3: Table S2E of online supplement "Results") in this work mainly refer to individual agents $(n=131)$, but also to mixed exposure(s) or multicomponent worksites or professions $(n=57)$ where heterogeneous exposure to irritating substances is common, e.g. swine confinement, "construction work" or "farming", giving 188 
Table 3 Overview of individual agents causing irritant-induced OA or occupational COPD

\begin{tabular}{|c|c|c|c|}
\hline Agent CAS & $\begin{array}{c}\text { Strength of evidence } \\
\text { (modified RCGP three star grading) }\end{array}$ & $\begin{array}{c}\text { Number of } \\
\text { studies per agent }\end{array}$ & References \\
\hline \multicolumn{4}{|l|}{ Acids } \\
\hline ", acetic & * & 3 & {$[108,157,158]$} \\
\hline \multicolumn{4}{|l|}{ 64-19-7 } \\
\hline ", not specified & $(*)$ & 2 & {$[30,37]$} \\
\hline ", dodecanedioic & - & 1 & [159] \\
\hline \multicolumn{4}{|l|}{$693-23-2-1$} \\
\hline ", various & - & 1 & [35] \\
\hline ", " (hydrochloric, hydrofluoric, nitric, perchloric, sulfuric) & - & 1 & [160] \\
\hline ", hydrochloric & $(*)$ & 6 & {$[35,99,161,162]$} \\
\hline \multicolumn{4}{|l|}{$7647-01-0$} \\
\hline ", hydrofluoric & - & 1 & [163] \\
\hline \multicolumn{4}{|l|}{$7664-39-3$} \\
\hline ", sulfuric & * & 3 & {$[99,109,164]$} \\
\hline \multicolumn{4}{|l|}{$7664-93-9$} \\
\hline \multicolumn{4}{|l|}{ Acrylates } \\
\hline ", not specified & - & 1 & [165] \\
\hline ", alkyl cyanoacrylates & $(*)$ & 4 & [166-169] \\
\hline ", cyanoacrylate glue & - & 1 & {$[170]$} \\
\hline ", " [loctite] & $*$ & 4 & {$[44,169,171,172]$} \\
\hline \multicolumn{4}{|l|}{ 53858-53-0 } \\
\hline ", methacrylates & $*$ & 1 & [134] \\
\hline ", methyl 2-cyanoacrylate & - & 3 & {$[166,169,173]$} \\
\hline \multicolumn{4}{|l|}{$137-05-3$} \\
\hline ", methylmethacrylate & - & 2 & {$[169,174]$} \\
\hline \multicolumn{4}{|l|}{$80-62-6$} \\
\hline Aluminum salts & * & 1 & {$[100]$} \\
\hline \multicolumn{4}{|l|}{ aluminum fluoride: 7724-18-1 } \\
\hline \multicolumn{4}{|l|}{ aluminum sulfate: $10043-01-3$} \\
\hline 2-Aminoethanol [2-ethanolamine] & - & 1 & {$[175]$} \\
\hline \multicolumn{4}{|l|}{$141-43-5$} \\
\hline Amino-ethyl-ethanolamine & - & 1 & {$[176]$} \\
\hline \multicolumn{4}{|l|}{$111-41-1$} \\
\hline 3-Amino-5-mercapto-1,2,4-triazole & $(*)$ & 1 & {$[177]$} \\
\hline \multicolumn{4}{|l|}{$16691-43-3$} \\
\hline Ammonia & $*$ & 6 & {$[41,178-182]$} \\
\hline \multicolumn{4}{|l|}{$7664-41-7$} \\
\hline Ammonium chloride (triple salt) & - & 1 & [183] \\
\hline \multicolumn{4}{|l|}{$12125-02-9$} \\
\hline Ammonium thioglycolate & - & 1 & [184] \\
\hline \multicolumn{4}{|l|}{$5421-46-5$} \\
\hline Amprolium hydrochloride & - & 1 & [185] \\
\hline $137-88-2$ & & & \\
\hline
\end{tabular}


Table 3 Overview of individual agents causing irritant-induced OA or occupational COPD (Continued)

\begin{tabular}{|c|c|c|c|}
\hline \multicolumn{4}{|l|}{ Anhydrides } \\
\hline ", various & $*$ & 2 & {$[186,187]$} \\
\hline ", dioctyl phthalate & - & 1 & [188] \\
\hline \multicolumn{4}{|l|}{$117-81-7$} \\
\hline ", hexahydrophthalic & - & 1 & [189] \\
\hline \multicolumn{4}{|l|}{$37226-48-5$} \\
\hline ", himic & - & 1 & [190] \\
\hline \multicolumn{4}{|l|}{$2746-19-2$} \\
\hline ", maleic & - & 2 & {$[191,192]$} \\
\hline \multicolumn{4}{|l|}{$108-31-6$} \\
\hline ", methyltetrahydrophthalic & - & 1 & [193] \\
\hline \multicolumn{4}{|l|}{$26590-20-9$} \\
\hline ", phthalic anhydride & $\left.*{ }^{*}\right]$ & 5 & [194-198] \\
\hline \multicolumn{4}{|l|}{$85-44-9$} \\
\hline ", pyromellitic dianhydride & - & 1 & [199] \\
\hline \multicolumn{4}{|l|}{$89-32-7$} \\
\hline ", tetrachlorophthalic anhydride & $*$ & 4 & [200], [201], [202], \\
\hline \multicolumn{4}{|l|}{$117-08-8$} \\
\hline $\begin{array}{l}\text { ", benzene-1, 2, 4- tricarboxylic acid 1,2-anhydride } \\
\text { [trimellitic anhydride] }\end{array}$ & ** & 5 & {$[197,204-207]$} \\
\hline \multicolumn{4}{|l|}{$552-30-7$} \\
\hline Aziridine, polyfunctional & $(*)$ & 2 & {$[208,209]$} \\
\hline \multicolumn{4}{|l|}{$64265-57-2$} \\
\hline Azobisformamide [azodicarbonamide] & * & 5 & {$[210-214]$} \\
\hline \multicolumn{4}{|l|}{$123-77-3$} \\
\hline Benzalkonium chloride (fumes) & - & 2 & {$[215,216]$} \\
\hline \multicolumn{4}{|l|}{$8001-54-5$} \\
\hline 1, 2-Benzisothiazoline-3-one (fumes) & - & 1 & [217] \\
\hline \multicolumn{4}{|l|}{$2634-33-5$} \\
\hline Bisulfite, SO2 & - & 1 & {$[37]$} \\
\hline \multicolumn{4}{|l|}{ SO2: 7446-09-5 } \\
\hline Bromine, hydrobromic acid & - & 1 & [218] \\
\hline Bromochlorodifluoromethane (Halon 1211) & - & 1 & [101] \\
\hline \multicolumn{4}{|l|}{$353-59-3$} \\
\hline Bromotrifluoromethane (Halon 1301) & - & 1 & [219] \\
\hline \multicolumn{4}{|l|}{$75-63-8$} \\
\hline Cadmium (fumes) & * & 4 & {$[68,220-222]$} \\
\hline \multicolumn{4}{|l|}{$7440-43-9$} \\
\hline Calcium carbonate [chalk powder] & - & 1 & [110] \\
\hline Calcium oxide & - & 1 & [35] \\
\hline \multicolumn{4}{|l|}{$1305-78-8$} \\
\hline Captafol (chlorinated thiocarboximide fungicide) & - & 1 & [223] \\
\hline \multicolumn{4}{|l|}{$2425-06-1$} \\
\hline Carbon black dust & * & 1 & [224] \\
\hline \multicolumn{4}{|l|}{$1333-86-4$} \\
\hline Chloramine T (powder dust) & $(*)$ & 5 & {$[225-229]$} \\
\hline $7080-50-4$ & & & \\
\hline
\end{tabular}


Table 3 Overview of individual agents causing irritant-induced OA or occupational COPD (Continued)

\begin{tabular}{|c|c|c|c|}
\hline Chlorhexidine & - & 1 & [230] \\
\hline \multicolumn{4}{|l|}{$55-56-1$} \\
\hline Chlorine & $* *$ & 11 & {$[35,165,231-239]$} \\
\hline \multicolumn{4}{|l|}{$7782-50-5$} \\
\hline Chromate (not specified) & $(*)$ & 9 & {$[240,241]$} \\
\hline \multicolumn{4}{|l|}{ [see also cement] } \\
\hline Cobalt & ** & 15 & {$[74,113,247-259]$} \\
\hline \multicolumn{4}{|l|}{$7440-48-4$} \\
\hline $\begin{array}{l}\text { 3-(Diamino-amino)propylamine 3-(dimethylamino) } \\
\text { propylamine] }\end{array}$ & $(*)$ & 1 & [260] \\
\hline \multicolumn{4}{|l|}{$109-55-7$} \\
\hline $\begin{array}{l}\text { Diamine, aliphatic + cycloaliphatic (hardener) 2855-13-2 } \\
\text { (isophorone diamine) }\end{array}$ & - & 1 & [261] \\
\hline Diazonium tetrafluoroborate $14239-22-6$ & - & 2 & {$[262,263]$} \\
\hline Dichlorodiethyl sulfide [mustard gas] $+505-60-2$ & $(*)$ & 1 & [264] \\
\hline Dichlorvos (organophosphate) & - & 2 & {$[265,266]$} \\
\hline \multicolumn{4}{|l|}{$62-73-7$} \\
\hline Diethanolamine & - & 1 & [267] \\
\hline \multicolumn{4}{|l|}{$111-42-2$} \\
\hline 2-Diethylaminoethanol [diethyl aminoethanol] & $(*)$ & 1 & [268] \\
\hline \multicolumn{4}{|l|}{$100-37-8$} \\
\hline 2-Dimethylaminoethanol [dimethyl ethanolamine] & - & 2 & {$[269,270]$} \\
\hline \multicolumn{4}{|l|}{$108-01-0$} \\
\hline$\underline{\text { Diinitrogen tetraoxide [dinitrogentetroxide] }}$ & $(*)$ & 1 & [271] \\
\hline \multicolumn{4}{|l|}{$10544-72-6$} \\
\hline Ethylenediamine [ethylene diamine] & $*$ & 6 & {$[168,184,272-275]$} \\
\hline \multicolumn{4}{|l|}{$107-15-3$} \\
\hline Ethylene oxide & - & 2 & {$[276,277]$} \\
\hline \multicolumn{4}{|l|}{$75-21-8$} \\
\hline Formaldehyde (gas, dust) & * & 9 & [278-283] \\
\hline \multicolumn{4}{|l|}{$50-00-0$} \\
\hline Freon, (freon-22) & - & 2 & {$[286,287]$} \\
\hline Glutaraldehyde [glutaral] & $*[*]$ & 9 & {$[74,83,288-294]$} \\
\hline \multicolumn{4}{|l|}{$11-30-8$} \\
\hline Hexachlorophene & - & 1 & [295] \\
\hline \multicolumn{4}{|l|}{$70-30-4$} \\
\hline Hexamethylenetetramine & * & 3 & {$[184,296,297]$} \\
\hline \multicolumn{4}{|l|}{$100-97-0$} \\
\hline Hydrazine & - & 1 & {$[30]$} \\
\hline \multicolumn{4}{|l|}{$302-01-2$} \\
\hline Iridium salt & - & 1 & [298] \\
\hline \multicolumn{4}{|l|}{ Isocyanates, isocyanurate } \\
\hline ", various (HDI, MDI, TDI) & $* *$ & 11 & $\begin{array}{c}{[57,83,148,149} \\
165,281,299-303] \\
\end{array}$ \\
\hline ", Diphenylmethane diisocyanate [MDI] & $* *$ & 7 & {$[304-310]$} \\
\hline \multicolumn{4}{|l|}{ 5873-54-1 } \\
\hline ", " prepolymers & - & 1 & [311] \\
\hline $\begin{array}{l}\text { ", Hexamethylene diisocyanate [HDI]; plus isodurane } \\
\text { Diisocyanate }\end{array}$ & $(*)$ & 3 & {$[312,313]$} \\
\hline
\end{tabular}


Table 3 Overview of individual agents causing irritant-induced OA or occupational COPD (Continued)

\begin{tabular}{|c|c|c|c|}
\hline $822-06-0$ & & & \\
\hline ", HDI biuret plus & & & {$[314]$} \\
\hline $4035-89-6$ & & & \\
\hline $\begin{array}{l}\text { ", 3-Isocyanatomethyl-3,5,5-trimethylcyclohexyl isocyanate } \\
\text { [isophorone diisocyanate, IPDI] }\end{array}$ & - & 1 & {$[315]$} \\
\hline $4098-71-9$ & & & \\
\hline ", Methyl isocyanate [MIC] & $*$ & 6 & {$[316-321]$} \\
\hline $624-83-9$ & & & \\
\hline ", 1,5-Naphthylene diisocyanate [NDI] & $(*)$ & [46] & {$[322-324]$} \\
\hline $3173-72-6$ & & & \\
\hline ", Polymethylene polyphenyl isocyanate & * & 1 & {$[325]$} \\
\hline $9016-87-9$ & & & \\
\hline ", Toluene diisocyanate, TDI 2,4: 584-84-9; & $* *$ & 12 & {$[35,125,165$,} \\
\hline 2,6:91-08-7 & & & \\
\hline ", Triglycidil isocyanurate & - & 1 & {$[335]$} \\
\hline $2451-62-1$ & & & \\
\hline ", Triphenylmethane triisocyanate & - & 1 & [336] \\
\hline Isothiazolinone & - & 1 & {$[337]$} \\
\hline $55965-84-9$ & & & \\
\hline Lauryl dimethyl benzyl ammonium chloride & - & 1 & [338] \\
\hline 139-07-1 & & & \\
\hline Metam sodium [methyldithiocarbamate] & - & 1 & [102] \\
\hline $144-54-7$ & & & \\
\hline Methylmercaptan & - & 1 & [165] \\
\hline 74-93-1 & & & \\
\hline Monoethanolamine & - & 1 & [184] \\
\hline $141-43-5$ & & & \\
\hline $\mathrm{N}$-methylmorpholine & {$[*]$} & 1 & [339] \\
\hline $109-02-4$ & & & \\
\hline Nickel sulphate & $(*)$ & 5 & {$[246,340-343]$} \\
\hline$\rightarrow$ anhydrous $7786-81-4$ & & & \\
\hline$\rightarrow$ hexahydrate 10101-97-0 & & & \\
\hline Ninhydrin $485-47-2$ & - & 1 & [335] \\
\hline Nitrogen chloride [nitrogen trichloride, trichloramine] & {$[*]$} & 2 & {$[150,344]$} \\
\hline $10025-85-1$ & & & \\
\hline Ozone (gassings) & * & 1 & [345] \\
\hline $10028-15-6$ & & & \\
\hline Palladium & - & 1 & [346] \\
\hline $7440-05-3$ & & & \\
\hline Paraphenylenediamine & $(*)$ & 1 & {$[347]$} \\
\hline $106-50-3$ & & & \\
\hline Paraquat & * & 2 & {$[128,151]$} \\
\hline 4685-14-7 & & & \\
\hline Persulfate & & & \\
\hline ", not specified & $(*)$ & 2 & {$[348,349]$} \\
\hline ", ammonium & - & 1 & [350] \\
\hline ", potassium (7727-21-1) and ammonium peroxydisufate & {$[*]$} & 5 & [351] \\
\hline$(7727-54-0)$ & & & \\
\hline
\end{tabular}


Table 3 Overview of individual agents causing irritant-induced OA or occupational COPD (Continued)

\begin{tabular}{|c|c|c|c|}
\hline ", alcalic & - & 1 & [352] \\
\hline ", Sodium persulfate & - & 1 & [353] \\
\hline \multicolumn{4}{|l|}{$7775-27-1$} \\
\hline $\begin{array}{l}\text { ", Dipotassium peroxo-peroxodisulfate [potassium } \\
\text { persulfate] } 7727-21-1\end{array}$ & - & 1 & {$[354]$} \\
\hline ", Diammonium peroxodisulfate [ammonium persulfate] & * & 4 & {$[355-357]$} \\
\hline \multicolumn{4}{|l|}{$7727-54-0$} \\
\hline Phenylglycine acid chloride & * & 1 & [358] \\
\hline \multicolumn{4}{|l|}{$39478-47-2$} \\
\hline Phosgene & - & 2 & {$[35,359]$} \\
\hline \multicolumn{4}{|l|}{$75-44-5$} \\
\hline Piperazine dihydrochloride & * & 3 & {$[130,176,274]$} \\
\hline \multicolumn{4}{|l|}{$142-64-3$} \\
\hline Platinum salts & $* *$ & 8 & {$[131,176,360-365]$} \\
\hline \multicolumn{4}{|l|}{$(7440-06-4)$} \\
\hline Polyethylene & - & 3 & {$[366-368]$} \\
\hline \multicolumn{4}{|l|}{$9002-88-4$} \\
\hline Polymethyl-methacrylate [plexiglas powder] & - & 1 & [369] \\
\hline \multicolumn{4}{|l|}{$9011-14-7$} \\
\hline Polypropylene, heated to $250^{\circ} \mathrm{C}$ & {$[*]$} & 2 & {$[370,371]$} \\
\hline \multicolumn{4}{|l|}{$9003-07-0$} \\
\hline Polyvinyl chloride (fume) & * & 8 & {$[53,372-376]$} \\
\hline \multicolumn{4}{|l|}{$9002-86-2$} \\
\hline Potassium dichromate & $(*)$ & 1 & [379] \\
\hline \multicolumn{4}{|l|}{ 7778-50-9 ( see also chromium;cement) } \\
\hline Potassium aluminum tetrafluoride & $(*)$ & 1 & [380] \\
\hline \multicolumn{4}{|l|}{$14484-69-6$} \\
\hline Rosin core solder, thermal decomposition [colophony] & * & 6 & {$[74,83,381-383]$} \\
\hline \multicolumn{4}{|l|}{$8050-09-7$} \\
\hline Sodium azide (powder dust) & - & 1 & [384] \\
\hline \multicolumn{4}{|l|}{$26628-22-8$} \\
\hline $\begin{array}{l}\text { Sodium iso-nonanoyl oxybenzene sulphonate } \\
\text { [SINOS] 123354-92-7 }\end{array}$ & $(*)$ & 3 & {$[385-387]$} \\
\hline Sodium metabisulfite [metabisulfite sodium] & $(*)$ & 6 & {$[103,388-392]$} \\
\hline \multicolumn{4}{|l|}{$7681-57-4$} \\
\hline Styrene monomer & $(*)$ & 3 & {$[132,393,394]$} \\
\hline \multicolumn{4}{|l|}{$100-42-5$} \\
\hline Sulfur dioxide & ${ }^{*}[*]$ & 5 & {$[35,154,395-397]$} \\
\hline \multicolumn{4}{|l|}{$7446-09-5$} \\
\hline Sulfathiazole & - & 1 & [398] \\
\hline \multicolumn{4}{|l|}{$72-14-0$} \\
\hline Terpene (3-carene) & - & 2 & {$[399,400]$} \\
\hline \multicolumn{4}{|l|}{$13466-78-9$} \\
\hline Tetrachloroisophthalonitrile (fungicide) & - & 1 & [401] \\
\hline Tetrahydrothiophene & - & 1 & [402] \\
\hline \multicolumn{4}{|l|}{$110-01-0$} \\
\hline $\begin{array}{l}\text { Tetramethrin [1-(5-tretrazoly)- 4-guanyl-tetrazene } \\
\text { hydrate] 7696-12-0 }\end{array}$ & - & 2 & {$[338,403]$} \\
\hline Tributyl tin oxide [carpet fungicide] & - & 1 & [404] \\
\hline
\end{tabular}


Table 3 Overview of individual agents causing irritant-induced OA or occupational COPD (Continued)

\begin{tabular}{|c|c|c|c|}
\hline Triethanolamine & - & 1 & {$[175]$} \\
\hline \multicolumn{4}{|l|}{$102-71-6$} \\
\hline Tungsten carbide & - & 1 & {$[405]$} \\
\hline \multicolumn{4}{|l|}{$11130-73-7$} \\
\hline Tylosin tartrate & - & 1 & [406] \\
\hline Uranium hexafluoride & - & 2 & {$[30,407]$} \\
\hline \multicolumn{4}{|l|}{$7783-81-5$} \\
\hline Urea (fume) & - & 1 & [104] \\
\hline \multicolumn{4}{|l|}{$57-13-6$} \\
\hline Urea formaldehyde foam & - & 1 & [408] \\
\hline \multicolumn{4}{|l|}{$64869-57-4 /$} \\
\hline \multicolumn{4}{|l|}{ Phenol-formaldehyde resin } \\
\hline \multicolumn{4}{|l|}{$9003-35-4$} \\
\hline Vanadium $7440-62-2$ + divanadium pentoxide & * & 5 & {$[84,409-412]$} \\
\hline \multicolumn{4}{|l|}{$1314-62-1$} \\
\hline Zinc (fume) & - & 3 & {$[413-415]$} \\
\hline \multicolumn{4}{|l|}{$7440-66-6$} \\
\hline Zinc chloride (fume) & - & 1 & [183] \\
\hline \multicolumn{4}{|l|}{$7646-85-7$} \\
\hline Mixed agent & Evidence level & $\begin{array}{c}\text { Number of studies } \\
\text { per agent }\end{array}$ & \\
\hline Acid fluxes & - & 1 & [74] \\
\hline Acrylic acid & - & 1 & {$[166]$} \\
\hline Airbag content & - & 1 & [416] \\
\hline Bleaching agent (fumes) & - & 1 & [99] \\
\hline Cement & ** & 14 & {$[111,133,235$,} \\
\hline $65997-15-1$ & & & 417-427] \\
\hline Chlorofluorocarbons & $(*)$ & 2 & {$[428,429]$} \\
\hline \multicolumn{4}{|l|}{ (degradation products) } \\
\hline Cleaning agents (not specified) & $*{ }^{*}[*]$ & 9 & $\begin{array}{l}15,37,41,112 \\
135,430-433]\end{array}$ \\
\hline ", detergents & - & 2 & {$[434,435]$} \\
\hline Coffee, green & $*$ & 5 & [436-440] \\
\hline Cotton (dust, raw) & ${ }^{*}[*]$ & $(12)$ & {$[48,114-116,423$} \\
\hline \multicolumn{4}{|l|}{ CNT 750} \\
\hline Cutting oil & - & 2 & {$[37,448]$} \\
\hline Diesel exhaust & * & 5 & {$[10,45,46,105,106]$} \\
\hline ECG ink & - & 2 & {$[449,450]$} \\
\hline $\begin{array}{l}\text { Endotoxin (see also cotton dust, swine confinement, } \\
\text { poultry confinement, house dust) }\end{array}$ & * & 2 & {$[41,451]$} \\
\hline Environmental tobacco smoke & $* *$ & 10 & $\begin{array}{c}{[117,118,138-143,} \\
452,453]\end{array}$ \\
\hline Floor sealant (aromatic hydrocarbons) & - & 1 & {$[30]$} \\
\hline Fumigating agent & - & 1 & [30] \\
\hline Furan-based binder & - & 1 & [454] \\
\hline Grain & $* *$ & 9 & $\begin{array}{c}{[48,122-124} \\
455-459]\end{array}$ \\
\hline ", rice & {$[*]$} & 1 & [460] \\
\hline Hairdressing chemicals & $(*)$ & 1 & [281] \\
\hline
\end{tabular}


Table 3 Overview of individual agents causing irritant-induced OA or occupational COPD (Continued)

\begin{tabular}{|c|c|c|c|}
\hline Lubricants (not specified) & $(*)$ & 2 & {$[10,57]$} \\
\hline Metal coat remover (coating removing chemical) & - & 1 & [30] \\
\hline Metal oxide (fume) & - & 1 & [461] \\
\hline Metal working fluids [MWF] & - & 1 & [462] \\
\hline Oil (spill) & * & 1 & [126] \\
\hline Paint (fumes) & * & 4 & {$[35,127,463,464]$} \\
\hline Paper dust $\mathrm{A} 111$ & $(*)$ & 1 & [48] \\
\hline Perfume agents (research lab) & - & 1 & {$[37,465]$} \\
\hline Pesticides (not specified) & $*^{*}[*]$ & 5 & $\begin{array}{c}{[129,152,266} \\
466,467]\end{array}$ \\
\hline Polyamines, aliphatic & {$\left[{ }^{*}\right]$} & 1 & {$[468]$} \\
\hline Polyester & $(*)$ & 2 & {$[469,470]$} \\
\hline Potroom aluminum smelting & ${ }^{*}[*]$ & 10 & {$[52,247,471-478]$} \\
\hline Powder paints & $(*)$ & 1 & {$[479]$} \\
\hline Pyrazolone (see reactive dye) & - & 1 & {$[480]$} \\
\hline Reactive dyes & $*$ & 5 & [481-485] \\
\hline Refractory ceramic fibers $[R C F]$ & * & 2 & {$[486,487]$} \\
\hline Smoke (fires, pyrolysis products) & $*{ }^{*}\left[{ }^{*}\right]$ & 5 & {$[30,41,488-490]$} \\
\hline ", (oil fire and dust storm) & $*$ & 1 & [491] \\
\hline ", (biomass, indoor) & $(*)$ & 1 & [492] \\
\hline Soldering flux (fumes) & $*$ & 4 & {$[183,493-495]$} \\
\hline Solvents (not specified) & * & 4 & {$[10,48,496,497]$} \\
\hline Spray paint & - & 1 & {$[30]$} \\
\hline Tall oil & - & 1 & [498] \\
\hline Tear gas & - & 4 & [499-502] \\
\hline Welding fumes & ** & 18 & $\begin{array}{l}{[41,48,57,83,247} \\
281,464,503-513]\end{array}$ \\
\hline Work-site or profession & Evidence level & $\begin{array}{l}\text { Number of studies per } \\
\text { work-site or profession }\end{array}$ & \\
\hline Ceramic production & ${ }^{*}[*]$ & 2 & {$[514,515]$} \\
\hline \multicolumn{4}{|l|}{ Cleaners } \\
\hline Construction work (dust, agent not specified) & $* *$ & 5 & $\begin{array}{c}{[8,107,136,} \\
516,517] \\
\end{array}$ \\
\hline \multicolumn{4}{|l|}{ Farming } \\
\hline ", (various) & ${ }^{*}[*]$ & 9 & $\begin{array}{l}{[119,120,144-} \\
146,518-521]\end{array}$ \\
\hline ", animals (pig, beef/veal, dairy, poultry) & *** & 3 & {$[522-524]$} \\
\hline Foundry & ${ }^{*}[*]$ & 4 & {$[121,147,525,526]$} \\
\hline \multicolumn{4}{|l|}{ [see also isocyanates (MDI)] } \\
\hline Health care workers & $*{ }^{*}\left[{ }^{*}\right]$ & 4 & {$[23,527-529]$} \\
\hline Metallurgical industry workers & * & 1 & [530] \\
\hline Poultry confinement & $*(*)$ & 4 & {$[153,531-533]$} \\
\hline Poultry confinement, slaughtery house & * & 3 & {$[534-536]$} \\
\hline Swine confinement & ** & 8 & $\begin{array}{c}{[39,40,141,155} \\
537-540]\end{array}$ \\
\hline World Trade Center disaster 2001 & $* *$ & 8 & {$[133,156,541-546]$} \\
\hline
\end{tabular}

[ ] down-grading due to lower quality of clinical investigations relative to the scale of the scientific level of the study.

${ }^{*}$ ) up-grading due to at least 5 cases without contradictory findings. 
different causes of irritant-induced OA and/or occupational COPD in total.

\section{Strength and limitations}

This work covers a broad range of causative agents of irritant-induced occupational asthma or COPD. We included various study designs.

A strength of our work is that we not only assessed the quality of single investigations but the strength of the body of evidence for each irritant agent.

The paradigm of "evidenced-based medicine" has been criticized by leading scientists [547-550]. Bias in the selection of information may be a problem for generalization of findings in single studies [551,552]. In spite of these limitations, alternative approaches to evaluation of the literature have not been generally accepted. Evaluation of the evidence depends on the domain, which means the factors to be considered in assessing the extent to which the study results are reliable or valid.

Kunz et al. [553] stressed the approach of grading scientific studies on basis of additional qualified data, i.e. dose response relationships. This latter was seen in 30/ 474 individual studies in this current work. Other studies were based on evidence by $\mathrm{OR}>2$ or $<0.5$ for irritant-induced OA and occupational COPD which was applied as an approach in 40/474 individual studies (see Additional file 3: Table S2E of online supplement "Results").

There are numerous procedural methods for rating the strength of scientific evidence. The AHRQ emphasized in 2002: "systems for grading the strength of a body of evidence are much less uniform than those for rating study quality" [554].

It is possible that not all relevant studies were found in our search of literature. Probably, some studies could not be found by the MeSH term raster applied. Relying solely on $\mathrm{MeSH}$ terms might be a problem in the identification of studies of irritant-induced OA or occupational COPD. We restricted the search to the MeSH fields in order to increase the specificity of the search. As for any electronic search strategy, an increase of specificity implies a decrease in sensitivity of the search.

For each single study, we took into consideration possible risks due to confounding, e.g. exposure to multiple agents and selection bias, e.g. healthy worker effect.

\section{Basis and quality of data}

Irritant-induced obstructive airways diseases cannot usually be diagnosed in one clinical visit and, instead, follow-up and/or detailed clinical investigations are necessary. The diagnostic "gold standard" for OA is SIC using a specific occupational agent in an exposure chamber. SIC is particularly indicated in the clinical setting where new causative substances with still unknown adverse respiratory sensitization potential are suspected. This "gold standard" is not applicable for large studies; so, it was used mainly in case series or reports.The evidence levels to confirm irritant-induced work-relaated asthma or occupational COPD for the listed irritant agents, professions or worksites (see Additional file 3: Table S2E of online supplement "Results") are frequently low with the major reasons being that high quality studies were missing and the quality of the available studies was low. Nevertheless, this knowledge is the best available and may help physicians to identify a suspected irritant agent as causative in irritant-induced work-related asthma and / or occupational COPD [555]. As also recently stressed by Quint et al. [555], "implementing an evidence-based identification and regulatory process for OA will help to ensure primary prevention of OA". In cases of low evidence level of an agent that does not exclude a causative role, caution should be exercised and a more detailed diagnostic testing of relevant exposure should be performed.

\section{Occupational COPD, an underestimated category}

We identified only 20 out of 474 publications that referred to occupational COPD, with most of them implicating inorganic or organic dust or fumes, such as cement dust, construction work and diesel exhaust, as the causative agents.

As an example, the mixed agent cement dust was investigated in 14 studies but only four studies documented cement dust as the causative agent in occupational COPD $[111,418,419,422]$ (see Table 3 and Additional file 3: Table S2E "Results"). The remaining 10 studies described irritantinduced OA cases [235,423-426,530] or identified significant asthma symptoms/ obstructive ventilation patterns without a clear diagnosis (5 studies: $[178,417,420,556])$. It can be assumed that if it had been considered on the other 10 studies then occupational COPD caused by cement dust would have been frequently observed.

The population-attributable fraction for COPD associated with occupational exposure has been estimated between $9 \%$ and $31 \%[1,64,65]$. However the true population-attributable risk due to occupational exposure is unclear [6,557] as occupational COPD is rarely clinically diagnosed. Blanc et al. [558] recently published an ecological analysis using data from three large studies, comprising the Burden of Obstructive Lung Disease study [169], the Latin American Project for Investigation of Obstructive Lung Disease (PLATINO) and the European Community Respiratory Health Survey follow-up (ECHRS II), where occupational COPD was also not a primary goal. The original publications are mainly concerned with OA or asthma symptoms, but a history of pre-existing OA or RADS cannot be allowed to exclude 
Table 4 Strength of evidence for agents, professions and work-site according to the modified RCGP three-star system [88]

\begin{tabular}{lll}
\hline $\begin{array}{l}\text { Evidence level } \\
\text { (modified RCGP }\end{array}$ & $\begin{array}{l}\text { Number of } \\
\text { agents/work-sites }\end{array}$ & $\begin{array}{l}\text { Agents, work-site or profession } \\
\text { three-star grading) }\end{array}$ \\
or professions & \\
\hline
\end{tabular}

\begin{tabular}{lll}
\hline$* * *$ & 0 & - \\
\hline$* *$ & 17 & Benzene-1, 2, 4-tricarboxylic acid-1,2-anhydride [trimellitic anhydride] (552-30-7); chlorine (7782-50-5);
\end{tabular}
cobalt (7440-48-4); various isocyanates, isocyanurate ( $\mathrm{HDI}, \mathrm{MDI}, \mathrm{TDI})$, diphenylmethane diisocyanate [MDI] (5873-54-1), toluene diisocyanate, TDI 2,4 (584-84-9), TDI 2,6: (91-08-7); platinum salts (7440-06-4); cement ; environmental tobacco smoke; grain ; welding fumes; construction work (dust, agent not specified); farming, animals (pig, beef/veal, dairy, poultry); swine confinement; World Trade Center disaster 2001

*[*] 12

Ceramic production; Phthalic anhydride (85-44-9); glutaraldehyde [glutaral] (11-30-8); sulfur dioxide (7446-09-5); cotton (dust, raw) CNT 750; potroom aluminum smelting; farming (various); foundry; smoke (fires, pyrolysis products); pesticides (not specified); cleaning agents (not specified); health care workers

* 39

Acetic acid (64-19-7); sulfuric acid (7664-93-9); metacrylates, loctide ${ }^{\circledR}$ (53858-53-0); aluminum salts [aluminum fluoride] (7724-18-1); aluminum sulfate: (10043-01-3); ammonia (7664-41-7); various anhydrides; tetrachlorophthalic anhydride (117-08-8); azobisformamide (123-77-3); cadmium (fumes) (7440-43-9); carbon black dust (1333-86-4); ethylenediamine (107-15-3); formaldehyde (gas, dust) (50-00-0); hexamethylenetetramine (100-97-0); methyl isocyanate [MIC] (624-83-9); naphthylene diisocyanate (3173-72-6); polymethylene polyphenyl isocyanate (9016-87-9); N-methylmorpholine (09-02-4); ozone (gassings) (10028-15-6); paraquat (4685-14-7); diammonium peroxodisulfate ( 7727-54-0); phenylglycine acid chloride (39478-47-2); piperazine dihydrochloride (142-64-3); polyvinyl chloride (fume) (9002-86-2); rosin core solder; thermal decomposition (8050-09-7); vanadium (7440-62-2) + divanadium pentoxide (1314-62-1); cleaning agents (not specified); green coffee ; diesel exhaust; endotoxin; oil (spill); paint (fumes); pesticides (not specified); reactive dyes; refractory ceramic fibers [RCF]; smoke (fires, pyrolysis products; oil fire and dust storm); soldering flux; solvents (not specified); health care workers; poultry confinement; slaughtery house; metallurgical industry workers

\begin{tabular}{lll}
\hline$\left.{ }^{*}\right]$ & 3 & $\begin{array}{l}\text { Nitrogen chloride (10025-85-1); polyamines, aliphatic; potassium persulfate (7727-21-1) and ammonium } \\
\text { peroxydisufate (7727-54-0); grain rice }\end{array}$ \\
\hline$\left.{ }^{*}\right)$ & Acids nom
\end{tabular}

$(*) \quad 29$

Acids not specified; hydrochloric acids (7647-01-0); alkyl cyanoacrylates; 3-amino-5-mercapto-1,2,4-triazole I(16691-43-3); aziridine, polyfunctional (64265-57-2); chloramine T (powder dust) (7080-50-4); chromate (not specified); 3-(diamino-amino)propylamine (109-55-7); dichlorodiethyl sulfide (505-60-2); 2-diethylaminoethanol (100-37-8); diinitrogen tetraoxide (10544-72-6); hexamethylene diisocyanate [HDI], plus isodurane diisocyanate (822-06-0); HDI biuret plus (4035-89-6); nickel sulphate anhydrous (7786-81-4); hexahydrate (10101-97-0); paraphenylenediamine (106-50-3); persulfate (not specified); polypropylene, heated to $250^{\circ} \mathrm{C}$ (9003-07-0); potassium dichromate (7778-50-9); potassium aluminum tetrafluoride (14484-69-6); sodium iso-nonanoyl oxybenzene sulphonate [SINOS] (123354-92-7); sodium metabisulfite (7681-57-4); styrene monomer (100-42-5); chlorofluorocarbons (degradation products); hairdressing chemicals; lubricants (not specified); paper dust A111; aliphatic polyamines; polyester; powder paints; smoke (biomass, indoor)

Acids various; dodecanedioic (693-23-2-1); hydrofluoric acids (7664-39-3); cyanoacrylate glue; methyl 2-cyanoacrylate (137-05-3); methylmethacrylate (80-62-6); 2-aminoethanol (141-43-5); amino-ethylethanolamine (111-41-1); ammonium chloride (triple salt) (12125-02-9); ammonium thioglycolate (5421-46-5); amprolium hydrochloride (137-88-2); dioctyl phthalate (117-81-7); hexahydrophthalic anhydrides (37226-48-5); himic anhydrides (2746-19-2); maleic anhydrides (108-31-6); methyltetrahydrophthalic anhydrides (26590-20-9); pyromellitic dianhydride (89-32-7); benzalkonium chloride (fumes) (8001-54-5); 1, 2-benzisothiazoline-3-one (fumes) (2634-33-5); bisulfite, SO2:(7446-09-5); hydrobromic acid bromine; bromochlorodifluoromethane [halon 1211] (353-59-3); bromotrifluoromethane [halon 1301](75-63-8); calcium carbonate [chalk powder]; calcium oxide (1305-78-8); captafol (2425-06-1); chlorhexidine (55-56-1); aliphatic + cycloaliphatic diamine, (hardener) (2855-13-2) [isophorone diamine]; diazonium tetrafluoroborate (14239-22-6); dichlorvos [organophosphate] (62-73-7); diethanolamine (111-42-2); 2-dimethylaminoethanol [dimethyl ethanolamine] (108-01-0); ethylene oxide (75-21-8); freon-22; hexachlorophene (70-30-4); hydrazine (302-01-2); iridium salt; isocyanate prepolymers; 3-isocyanatomethyl-3,5,5-trimethylcyclohexyl isocyanate (4098-71-9); triglycidil isocyanurate (2451-62-1): triphenylmethane triisocyanate; isothiazolinone (55965-84-9); lauryl dimethyl benzyl ammonium chloride (139-07-1); metam sodium (144-54-7); methylmercaptan (74-93-1); monoethanolamine (141-43-5); ninhydrin (485-47-2); palladium (7440-05-3); ammonium persulfate; alcalic persulfate; sodium persulfate (7775-27-1); dipotassium peroxo-peroxodisulfate (7727-21-1); phosgene (75-44-5); polyethylene (9002-88-4); polymethyl-methacrylate (9011-14-7); sodium azide (powder dust) (26628-22-8); sulfathiazole (2-14-0); terpene (3-carene) (3466-78-9); tetrahydrothiophene (110-01-0); tetrachloroisophthalonitrile (fungicide); tetramethrin (7696-12-0); tributyl tin oxide; triethanolamine (102-71-6); tungsten carbide (11130-73-7); turpentine (8006-64-2); tylosin tartrate; uranium hexafluoride (7783-81-5); urea (fume) 
occupational COPD [559]. Blanc et al. [558] stressed that the contribution of occupational exposure cannot be ignored, because "the association between adverse working conditions and COPD (...) carries significance as a global finding (...), alongside the (...) critical contribution of cigarette smoking to disease prevalence".

General acceptance of this statement does not exist [66,559], although evidence for an association between individual exposure levels and COPD is accumulating in the latest literature $[1,6,106,506,557,560,561]$.

\section{Irritant-induced WRA - a broader definition}

Irritant-induced OA includes three subcategories that predominantly differ according to the concentration of irritants in the workplace atmosphere. It can occur without a latency period, such as RADS, as was shown for 46 causative agents in our study, with the highest prevalence after spills of acids or tear gas (see Additional file 3: Table S2E of online supplement "Results"). Other agents, e.g. isocyanates or welding fumes, usually induce a slower onset of low dose irritant-induced asthma with a latency period and mostly without evidence of an IgEmediated pathomechanism.

The ACCP also stated in its last Consensus Statement in 2008 [24] that cases who do not meet the stringent criteria of RADS [30] (e.g. where there is a lag of several days before the onset of symptoms or where there is no single massive exposure but rather repeated exposure over days and weeks) should be subsumed into a broader category of irritant-induced OA. As outlined in the section "Introduction" Brooks et al. [31] and later also others, e.g. Burge [27] suggested using the term "not so sudden onset of irritant-induced asthma" for those developing the disorder after such exposure within a period of 2 days to 4 months. In an extended definition corresponding to ours, Burge [27] he used the term "low dose irritant-induced OA" for those developing the disorder after relatively low repeated exposure for more than 4 months.

Bardana [562] and Vandenplas and Malo [563] questioned whether such rather low concentrations could actually cause irritant-induced OA. These different opinions about the pathogenetic role of chronic or recurrent exposure(s) to low concentrations of respiratory irritants seem to be due to inadequate considering of the increased susceptibility of a small group of workers. Occupational disease statistics do mostly neither contain such cases nor work-aggravated asthma cases so far.

Another critical issue is the frequent disregarding of work-aggravated asthma due to occupational agents by physicians.

\section{Comparison to occupational guidelines or consensus statements - what is new?}

In the current analysis, the focus has been on irritant agents causing irritant-induced occupational asthma and COPD. Both entities have been underestimated or even overlooked in the past. Occupational COPD has not been considered as a subgroup of COPD thus so far $[559,564]$; and the definition of irritant-induced OA has been heterogenous at best $[24,552,565,566]$. Furthermore, the guidelines dealing with respiratory disorders have not even considered causation by individual irritant agents, so far.

The ACCP published a Consensus Statement in 2008 [24] which focuses on the diagnosis and management of WRA after a latency period, i.e. due allergens and "sensitizers" with unknown pathomechanisms, effectively sidelining irritant-induced OA to RADS.

The Agency for Healthcare Research and Quality (AHRQ) in its the Evidence Report "Diagnosis and Management of WRA" [552] addressed the key question of the best diagnostic approach for a patient with suspected WRA. In respect of irritant-induced OA, they only considered RADS as a non-allergic asthma due to mainly low molecular weight compounds of unknown pathomechanism.

The Canadian Thoracic Society "Guidelines for OA" [567] was the first evidence-based guideline, although irritant-induced OA was limited to RADS. If criteria were not fulfilled then irritant-induced OA was discussed as a controversial diagnosis. The three evidence levels in the "Guidelines for OA" were based on quality of scientific evidence within analyzed studies [568]. Compared with the modified RCGP three-star grading (see Additional file 2: Table S2D in online supplement "Methodology"), the different levels are defined in a more general way, i.e. not considering the quantitative aspect if only studies with lower scientific evidence exist. 
The evidence review and recommendations for OA by the BOHRF $[3,569]$ were designed to improve the prevention, identification and management of OA. This work mainly deals with asthma after a latency period and considers irritant-induced OA and RADS to be closely related entities. The difference in comparison with our analysis is obvious even though our evidencebased approach was closely related to the BOHRF guidelines and used the same grading systems.

In summary, the existing guidelines or statements mostly define irritant-induced OA as RADS. Workaggravated asthma, and occupational COPD as a distinct entity, have not been considered in any guideline, although the latter is becoming recognized as such in more recent publications $[557,559,564]$.

This evidence-based approach is the first which focuses on especially irritative agents within the broader definition of irritant-induced $\mathrm{OA}$ and occupational COPD. For clarification, the grading systems were modified in accordance with BOHRF [3] when considering the extent and quality of the clinical investigations, with the goal of creating evidence levels for causative irritative agents as precisely as possible.

\section{Concluding remarks}

$\mathrm{OA}$ is the most common chronic occupational lung disease in many industrialized countries [3]. COPD is the fourth leading cause of death worldwide with a significant portion of occupational cases [66]. The term occupational COPD does not officially exist. However, it has to be considered as a subcategory of COPD [559].

Our study shows that reliable, sensitive and specific methods are required in the diagnostic approach for confirming irritant-induced OA, work-aggravated asthma, or occupational COPD. The specific diagnostic work-up in a subject with such a suspected disorder depends on the individual clinical data and on the knowledge of asthma- or COPD-inducing agents in the workplace. On this basis, our review may help in diagnostics especially for agent exposures where we were able to relate irritant-induced work-related asthma or occupational COPD to a high evidence-based level (i.e. two stars according to the RCGP grading).

We have created a list representing the strength of evidence for irritating agents to be causative in irritantinduced work-related asthma or occupational COPD (see Additional file 3: Table S2E of online supplement "Results").

A low level or absence of evidence for many agents in causing irritant-induced work-related asthma or occupational COPD is sometimes due to contradictory findings in literature, but is mostly due to the absence of rigorous scientific studies, with many gaps remaining in the knowledge of a causative role for individual agents and conditions. Therefore, and because of rarely applied diagnostic approach in the clinical setting, our literature search and evaluation lead us to assume that irritant-induced respiratory disorders are considerably underreported in cross-sectional studies and occupational disease statistics.

Our list needs updating in the light of recent literature, in order to provide a realistic overview of agents and evidence level in their causation of irritant-induced workrelated or occupational COPD.

The estimated high population-attributable risk in the range of 5-25\% for occupational asthma and COPD from occupational exposure, indicates that more detailed and intensive research, as well as strategies designed to prevent these disorders, should receive high priority in the global efforts to reduce the burden of these diseases. This implies extended evidence-based diagnostic procedures that help to optimize primary and secondary prevention by the physicians dealing with occupational diseases.

Reduction of the exposure to noxious agents by lowering the permissible exposure limits is the best and favoured way for intervention. If this is not possible then other effective primary preventive measures, such as wearing adequate respiratory devices, are required [28,570-574].

Finally, we would like to mention that the diagnosis of irritant-induced OA should be considered if:

- there has been exposure to high concentration of an irritative agent identified in this study and the development of asthma without a latency period (original definition of RADS) or

- there has been chronic or repeated exposures to moderate (in the TLV ranges) concentrations of an irritative agent identified in this review and the development of asthma with a latency period, but without evidence of an IgE-mediated pathomechanism and

- there is evidence that a highly susceptible subject (e.g. with pre-existing NSBHR) develops new onset asthma upon occupational exposure to an identified irritative agent even at concentrations below the TLV.

Work-aggravated asthma should be considered if:

- there have been any of the before-mentioned exposures and

- there is a temporally related significant worsening of a pre-existing asthma or of a concomitant nonoccupational asthma.

The diagnosis of occupational COPD should be considered if: 
- there has been exposure to an agent capable of causing occupational COPD, and

- not reversible chronic airway disease is demonstrated and

- there is a temporal relationship between the period of exposure (mostly cumulative exposures to identified irritants ) and the development of COPD (acute WRA symptoms are frequently missing).

Occupational COPD has to be taken into consideration especially in non-smokers, i.e. when dominating non-occupational causes for COPD are obviously not present.

\section{Endnotes}

${ }^{a}$ Epidemiologic study design which is generally applied to test one or more specific hypotheses, typically whether an exposure is a risk factor for a disease [575].

\section{Additional files}

\section{Additional file 1: Economic burden.}

Additional file 2: "Methodology" Selection criteria, information sources, strength of evidence. Table A: Data extraction and synthesis. Table B. Quality assessment of individual study. Table C - The revised Scottish Intercollegiate Guidelines Network (SIGN) grading system (modifications are given in italics) [87]. Table D The Royal College of General Practitioners (RCGP) three-star system [88] used by the British Occupational Health Research Foundation [3,574] (modifications are given in italics).

Additional file 3: "Results" Table E overview on publications and SIGN grading of reporting OA or occupational COPD due to irritants. X. Baur, P. Bakehe, H. Vellguth www.eomsociety.org $=>$ Knowledge Center.

\section{Abbreviations}

CAS: Chemical abstracts service; COPD: Chronic obstructive pulmonary disease; OA: Occupational asthma; RADS: Reactive airways dysfunction syndrome; RCGP: Royal college of general practitioners; SIGN: Scottish intercollegiate guideline network; WRA: Work-related asthma.

\section{Competing interests}

The authors declare that they have no conflict of interest.

\section{Authors' contributions}

All authors made substantial contributions to the study. XB made the design of the study and the final interpretation of data. HV and PB did the detailed literature search, data extraction and analyses, and statistical analyses. XB and HV wrote the manuscript with input from PB. All authors approved the final version for submission.

\section{Acknowledgements}

We thank Marcial Velasco Garrido for critical review and support in drafting the manuscript.

Received: 20 April 2012 Accepted: 12 September 2012

Published: 26 September 2012

\section{References}

1. Balmes J, Becklake M, Blanc P, Henneberger P, Kreiss K, Mapp C, Milton D, Schwartz D, Toren K, Viegi G: American Thoracic Society Statement:
Occupational contribution to the burden of airway disease. Am J Respir Crit Care Med 2003, 167(5):787-797.

2. Bernstein IL, Chan-Yeung M, Malo JL, Bernstein DI: Asthma in the workplace and related conditions. 3rd edition. New York: Taylor \& Francis; 2006.

3. Nicholson PJ, Cullinan P, Burge PS, Boyle C: Occupational asthma: Prevention, identification \& management: Systematic review \& recommendations. London: British Occupational Health Research Foundation; 2010. http://www.bohrf. org.uk/downloads/OccupationalAsthmaEvidenceReview-Mar2010.pdf.

4. Arif AA, Whitehead LW, Delclos GL, Tortolero SR, Lee ES: Prevalence and risk factors of work related asthma by industry among United States workers: data from the third national health and nutrition examination survey (1988-94). Occup Environ Med 2002, 59(8):505-511.

5. Bakke PS, Baste V, Hanoa R, Gulsvik A: Prevalence of obstructive lung disease in a general population: relation to occupational title and exposure to some airborne agents. Thorax 1991, 46(12):863-870.

6. Becklake MR: Occupational exposures: evidence for a causal association with chronic obstructive pulmonary disease. Am Rev Respir Dis 1989, 140(3 Pt 2):S85-S91.

7. Becklake MR, Malo J-L, Chan-Yeung MY: Epidemiological approaches in occupational asthma. In Asthma in the workplace. 3rd edition. Edited by Bernstein IL, Chan-Yeung M, Malo J-L, Bernstein DI. New York, London: Taylor \& Francis Group; 2006:37-85.

8. Bergdahl IA, Toren K, Eriksson K, Hedlund U, Nilsson T, Flodin R, Jarvholm B: Increased mortality in COPD among construction workers exposed to inorganic dust. Eur Respir J 2004, 23(3):402-406.

9. Blanc PD, Toren K: How much adult asthma can be attributed to occupational factors? Am J Med 1999, 107(6):580-587.

10. Henneberger PK, Derk SJ, Davis L, Tumpowsky C, Reilly MJ, Rosenman KD, Schill DP, Valiante D, Flattery J, Harrison R, et al: Work-related reactive airways dysfunction syndrome cases from surveillance in selected US states. J Occup Environ Med 2003, 45(4):360-368.

11. Karjalainen A, Kurppa K, Martikainen R, Klaukka T, Karjalainen J: Work is related to a substantial portion of adult-onset asthma incidence in the Finnish population. Am J Respir Crit Care Med 2001, 164(4):565-568.

12. Kogevinas M, Anto JM, Sunyer J, Tobias A, Kromhout H, Burney P: Occupational asthma in Europe and other industrialised areas: a population-based study. European Community Respiratory Health Survey Study Group. Lancet 1999, 353(9166):1750-1754.

13. Leuenberger $P$, Schindler $C$, Schwartz J, Ackermann-Liebrich U, Tara D, Perruchoud AP, Wuthrich B, Zellweger JP, Blaser K, Bolognini G, et al: Occupational exposure to inhalative irritants and methacholine responsiveness. Scand J Work Environ Health 2000, 26(2):146-152

14. Le Moual N, Kennedy SM, Kauffmann F: Occupational exposures and asthma in 14,000 adults from the general population. Am J Epidemiol 2004, 160(11):1108-1116.

15. Medina-Ramon M, Zock JP, Kogevinas M, Sunyer J, Anto JM: Asthma symptoms in women employed in domestic cleaning: a community based study. Thorax 2003, 58(11):950-954.

16. Meldrum M, Rawbone R, Curran AD, Fishwick D: The role of occupation in the development of chronic obstructive pulmonary disease (COPD). Occup Environ Med 2005, 62(4):212-214.

17. Taylor AJ: Respiratory irritants encountered at work. Thorax 1996, 51(5):541-545.

18. Petsonk EL: Work-related asthma and implications for the general public. Environ Health Perspect 2002, 110(Suppl 4):569-572.

19. Viegi G, Di Pede C: Chronic obstructive lung diseases and occupational exposure. Curr Opin Allergy Clin Immunol 2002, 2(2):115-121.

20. WHO: Reducing Risks, Promoting Healthy Life. In The World Health Report 2002. Geneva: WHO; 2002.

21. Xu X, Christiani DC, Dockery DW, Wang L: Exposure-response relationships between occupational exposures and chronic respiratory illness: a community-based study. Am Rev Respir Dis 1992, 146(2):413-418.

22. Toren K, Blanc PD: Asthma caused by occupational exposures is common - a systematic analysis of estimates of the population-attributable fraction. BMC Pulm Med 2009, 9:7.

23. Kogevinas $M$, Zock JP, Jarvis $D$, Kromhout $H$, Lillienberg L, Plana E, Radon $K$ Toren K, Alliksoo A, Benke G, et al: Exposure to substances in the workplace and new-onset asthma: an international prospective population-based study (ECRHS-II). Lancet 2007, 370(9584):336-341. 
24. Tarlo SM, Balmes J, Balkissoon R, Beach J, Beckett W, Bernstein D: Diagnosis and management of work-related asthma: American College of Chest Physicians Consensus Statement. Chest 2008, 134:1-41.

25. Henneberger PK, Redlich CA, Callahan DB, Harber P, Lemiere C, Martin J, Tarlo SM, Vandenplas O, Toren K: An official american thoracic society statement: work-exacerbated asthma. Am J Respir Crit Care Med 2011, 184(3):368-378.

26. Lemiere C, Forget A, Dufour MH, Boulet LP, Blais L: Characteristics and medical resource use of asthmatic subjects with and without workrelated asthma. J Allergy Clin Immunol 2007, 120(6):1354-1359.

27. Burge SP, Moore VC, Robertson AS: Sensitization and irritant-induced occupational asthma with latency are clinically indistinguishable. Occup Med (Lond) 2012, 62(2):129-133.

28. Baur $X$, Sigsgaard T, Aasen TB, Burge PS, Heederik D, Henneberger $P$, Maestrelli P, Rooyackers J, Schlunssen V, Vandenplas O, et al: Guidelines for the management of work-related asthma. Eur Respir J 2012, 39(3):529-545.

29. Baur $X$, Aasen TB, Burge PS, Heederik D, Henneberger PK, Maestrelli $P$, Schlunssen $V$, Vandenplas $O$, Wilken D: The management of work-related asthma guidelines: a broader perspective. Eur Respir Rev 2012, 21(124):125-139.

30. Brooks SM, Weiss MA, Bernstein IL: Reactive airways dysfunction syndrome (RADS). Persistent asthma syndrome after high level irritant exposures. Chest 1985, 88(3):376-384.

31. Brooks SM, Hammad Y, Richards I, Giovinco-Barbas J, Jenkins K: The spectrum of irritant-induced asthma: sudden and not-so-sudden onset and the role of allergy. Chest 1998, 113(1):42-49.

32. Chan-Yeung M, Lam S, Kennedy SM, Frew AJ: Persistent asthma after repeated exposure to high concentrations of gases in pulpmills. Am J Respir Crit Care Med 1994, 149(6):1676-1680.

33. Humerfelt S, Gulsvik A, Skjaerven R, Nilssen S, Kvale G, Sulheim O, Ramm E, Eilertsen E, Humerfelt SB: Decline in FEV1 and airflow limitation related to occupational exposures in men of an urban community. Eur Respir J 1993 6(8):1095-1103.

34. Krzyzanowski M, Jedrychowski W, Wysocki M: Factors associated with the change in ventilatory function and the development of chronic obstructive pulmonary disease in a 13-year follow-up of the Cracow Study. Risk of chronic obstructive pulmonary disease. Am Rev Respir Dis 1986, 134(5):1011-1019.

35. Tarlo SM, Broder I: Irritant-induced occupational asthma. Chest 1989, 96(2):297-300

36. Gautrin D, Bernstein IL, Brooks SM, Henneberger PK: Reactive airways dysfunction syndrome and irritant-induced asthma. In Asthma in the workplace. Edited by Bernstein IL, Chan-Yeung M, Malo JL, Bernstein DI. New York, London: Taylor \& Francis Group; 2006:581-629.

37. Kipen HM, Blume R, Hutt D: Asthma experience in an occupational and environmental medicine clinic. Low-dose reactive airways dysfunction syndrome. J Occup Med 1994, 36(10):1133-1137.

38. Dykewicz MS: Occupational asthma: current concepts in pathogenesis, diagnosis, and management. J Allergy Clin Immunol 2009, 123(3):519-528. quiz 529-530

39. Cormier Y, Coll B, Laviolette M, Boulet LP: Reactive airways dysfunction syndrome (RADS) following exposure to toxic gases of a swine confinement building. Eur Respir J 1996, 9(5):1090-1091.

40. Dosman JA, Lawson JA, Kirychuk SP, Cornier Y, Biem J, Koehncke N: Occupational asthma in newly employed workers in intensive swine confinement facilities. Eur Respir J 2004, 24:698-702.

41. Reinisch F, Harrison RJ, Cussler $S$, Athanasoulis M, Balmes J, Blanc $P$, Cone J: Physician reports of work-related asthma in California, 1993-1996. Am J Ind Med 2001, 39(1):72-83.

42. Liss GM, Tarlo SM, Doherty J, Purdham J, Greene J, McCaskell L, Kerr M: Physician diagnosed asthma, respiratory symptoms, and associations with workplace tasks among radiographers in Ontario, Canada. Occup Environ Med 2003, 60(4):254-261.

43. Smedley J, Coggon D: Health surveillance for hospital employees exposed to respiratory sensitizers. Occup Med (Lond) 1996, 46(1):33-36.

44. Toren K, Jarvholm B, Brisman J, Hagberg S, Hermansson BA, Lillienberg L: Adult-onset asthma and occupational exposures. Scand J Work Environ Health 1999, 25(5):430-435.

45. Makker HK, Ayres JG: Work-related asthma in an aircraft engine mechanic. Respir Med 1999, 93(1):69-70.
46. Wade JF 3rd, Newman LS: Diesel asthma. Reactive airways disease following overexposure to locomotive exhaust. J Occup Med 1993 35(2):149-154

47. Baur $X$ : Airborne allergens and irritants in the workplace. In Allergy and allergic diseases. Edited by Kay AB, Kaplan AP, Bousquet J, Holt PG. Boston: Blackwell Publishing; 2008:1017-1122.

48. Toren K, Balder B, Brisman J, Lindholm N, Lowhagen O, Palmqvist M, Tunsater A: The risk of asthma in relation to occupational exposures: a case-control study from a Swedish city. Eur Respir J 1999, 13(3):496-501.

49. Hnizdo E, Sullivan PA, Bang KM, Wagner G: Association between chronic obstructive pulmonary disease and employment by industry and occupation in the US population: a study of data from the Third National Health and Nutrition Examination Survey. Am J Epidemiol 2002, 156(8):738-746.

50. Oxman AD, Muir DC, Shannon HS, Stock SR, Hnizdo E, Lange HJ: Occupational dust exposure and chronic obstructive pulmonary disease. A systematic overview of the evidence. Am Rev Respir Dis 1993, 148(1):38-48.

51. Marine WM, Gurr D, Jacobsen M: Clinically important respiratory effects of dust exposure and smoking in British coal miners. Am Rev Respir Dis 1988, 137(1):106-112.

52. Kongerud J, Gronnesby JK, Magnus P: Respiratory symptoms and lung function of aluminum potroom workers. Scand J Work Environ Health 1990, 16(4):270-277.

53. Andrasch RH, Bardana EJ Jr, Koster F, Pirofsky B: Clinical and bronchial provocation studies in patients with meatwrappers' asthma. J Allergy Clin Immunol 1976, 58(2):291-298.

54. Carlsen KH, Anderson SD, Bjermer L, Bonini S, Brusasco V, Canonica W, Cummiskey J, Delgado L, Del Giacco SR, Drobnic F, et al: Exercise-induced asthma, respiratory and allergic disorders in elite athletes: epidemiology, mechanisms and diagnosis: Part I of the report from the Joint Task Force of the European Respiratory Society (ERS) and the European Academy of Allergy and Clinical Immunology (EAACI) in cooperation with GA2LEN. Allergy 2008, 63:387-403.

55. Karjalainen A, Kurppa K, Virtanen S, Keskinen H, Nordman H: Incidence of occupational asthma by occupation and industry in Finland. Am J Ind Med 2000, 37(5):451-458.

56. Hansson SO: Critical effects and exposure limits. Risk Anal 1997, 17(2):227-236

57. Latza U, Baur X: Occupational obstructive airway diseases in Germany: Frequency and causes in an international comparison. Am J Ind Med 2005, 48(2):144-152.

58. Chan-Yeung M, Malo JL: Aetiological agents in occupational asthma. Eur Respir J 1994, 7(2):346-371.

59. Fernandez-Nieto M, Quirce S, Sastre J: Occupational asthma in industry. Allergol Immunopathol (Madr) 2006, 34(5):212-223.

60. Baur X, Latza U: Non-malignant occupational respiratory diseases in Germany in comparison with those of other countries. Int Arch Occup Environ Health 2005, 78(7):593-602.

61. Ameille J, Pauli G, Calastreng-Crinquand A, Vervloet D, Iwatsubo Y, Popin E, Bayeux-Dunglas MC, Kopferschmitt-Kubler MC: Reported incidence of occupational asthma in France, 1996-99: the ONAP programme. Occup Environ Med 2003, 60(2):136-141.

62. Tarlo SM, Liss GM: Occupational asthma: an approach to diagnosis and management. CMAJ 2003, 168(7):867-871.

63. Pesci A, Majori M, Cuomo A, Borciani N, Bertacco S, Cacciani G, Gabrielli M: Neutrophils infiltrating bronchial epithelium in chronic obstructive pulmonary disease. Respir Med 1998, 92(6):863-870.

64. Hnizdo E, Glindmeyer HW, Petsonk EL, Enright P, Buist AS: Case definitions for chronic obstructive pulmonary disease. Copd 2006, 3(2):95-100.

65. Trupin L, Earnest G, San Pedro M, Balmes JR, Eisner MD, Yelin E, Katz PP, Blanc PD: The occupational burden of chronic obstructive pulmonary disease. Eur Respir J 2003, 22(3):462-469.

66. Balmes JR: Occupational airways diseases from chronic low-leve exposures to irritants. Clin Chest Med 2002, 23(4):727-735. vi.

67. Hendrick DJ: Smoking, cadmium, and emphysema. Thorax 2004, 59(3):184-185.

68. Davison AG, Fayers PM, Taylor AJ, Venables KM, Darbyshire J, Pickering CA, Chettle DR, Franklin D, Guthrie CJ, Scott MC, et al: Cadmium fume inhalation and emphysema. Lancet 1988, 1(8587):663-667. 
69. American Thoracic Society: Standards for the diagnosis and care of patients with chronic obstructive pulmonary disease. Am J Respir Crit Care Med 1995, 152:77-121.

70. Postma DS, Boezen HM: Rationale for the Dutch hypothesis. Allergy and airway hyperresponsiveness as genetic factors and their interaction with environment in the development of asthma and COPD. Chest 2004, 126(2 Suppl):96S-104S. discussion 159S-161S.

71. Balmes JR: Work-related COPD. Eur Respir J 1994, 7:768-778.

72. Bourdin A, Serre I, Flamme H, Vic P, Neveu D, Aubas P, Godard P, Chanez P. Can endobronchial biopsy analysis be recommended to discriminate between asthma and COPD in routine practice? Thorax 2004, 59(6):488-493.

73. Hargreave FE, Parameswaran K: Asthma, COPD and bronchitis are just components of airway disease. Eur Respir J 2006, 28(2):264-267.

74. Gannon PF, Burge PS: The SHIELD scheme in the West Midlands Region, United Kingdom. Midland Thoracic Society Research Group. Br J Ind Med 1993, 50(9):791-796

75. Eisner MD, Yelin EH, Katz PP, Lactao G, Iribarren C, Blanc PD: Risk factors for work disability in severe adult asthma. Am J Med 2006, 119(10):884-891

76. Toren K, Brisman J, Olin AC, Blanc PD: Asthma on the job: work-related factors in new-onset asthma and in exacerbations of pre-existing asthma. Respir Med 2000, 94(6):529-535.

77. Brändli O, Schindler C, Leuenberger PH, Baur X, Degens P, Kunzli N, Keller R, Perruchoud AP: Re-estimated equations for 5 th percentiles of lung function variables. Thorax 2000, 55(2):173-174.

78. European Parliament, The Council of EU: Regulation (EC) No 1272/2008 of the European Parliament and on the Council of 16 December 2008 on classification, labelling and packing of substances and mixtures, amending and repealing Directives 67/548/EEC and 1999/45/EC, and amending Regulations (EC) No 1907/2006. Off J EU 2008, L 353:1-1355. http://eur-lex.europa.eu/LexUriServ/LexUriServ.do?uri=OJ: L:2008:353:0001:0001:en:PDF.

79. American Conference of Governmental Industrial Hygienists: TLVs ${ }^{\circledR}$ and $B E / s^{\circledR}$. Threshold limit values for chemical substances and physical agents \& biological exposure indices. Cincinnaty: ACGIH; 2009.

80. Baur X: Occupational agents with respiratory effects according to ACGIH 2009 and / or classified with the R42 phrase* (may cause sensitization by inhalation) and / or with the R37 phrase* (irritating to respiratory system) according to the European Union directives 67/548/EEC (1), 2001/59/EC (2), 2004/73/EC (3) or 2009/2/EC (4) (identical to ILO/CIS 2002. 2009, http://www.lo.org/public/english/protection/safework/cis/ products/icsc/dtasht/riskphrs/index.htm) http://www.uke.de/institute/ arbeitsmedizin/downloads/universitaetsprofessur-arbeitsmedizin/ R42_und_R37A-EU09.pdf and www.eomsociety.org $=>$ knowledge center.

81. Meyer JD, Holt DL, Chen Y, Cherry NM, McDonald JC: SWORD '99: surveillance of work-related and occupational respiratory disease in the UK. Occup Med (Lond) 2001, 51(3):204-208.

82. Meyer JD, Holt DL, Cherry NM, McDonald JC: SWORD '98: surveillance of work-related and occupational respiratory disease in the UK. Occup Med (Lond) 1999, 49(8):485-489.

83. Ross DJ, Keynes HL, McDonald JC: SWORD '96: surveillance of workrelated and occupational respiratory disease in the UK. Occup Med (Lond) 1997, 47(6):377-381.

84. Esterhuizen TM, Hnizdo E, Rees D: Occurrence and causes of occupational asthma in South Africa-results from SORDSA's Occupational Asthma Registry, 1997-1999. S Afr Med J 2001, 91(6):509-513.

85. Buckley LA, Jiang XZ, James RA, Morgan KT, Barrow CS: Respiratory tract lesions induced by sensory irritants at the RD50 concentration. Toxicol Appl Pharmacol 1984, 74(3):417-429.

86. Haupt B, Drechsel-Schlund C, Guldner K, Rogosky E, Plinske W, Butz M: Dokumentation des Berufskrankheiten-Geschehens in Deutschland. BK-DOK 2005. Sankt Augustin: Deutsche Gesetzliche Unfallversicherung (DGUV); 2007. http://www.dguv.de/inhalt/zahlen/documents/bk_dok_2005.pdf

87. Harbour R, Miller J: A new system for grading recommendations in evidence based guidelines. BMJ 2001, 323(7308):334-336.

88. The Royal College of General Practitioners RCGP: The development and implementation of clinical guidelines. In Report of the Clinical Guidelines Working Group. London: RCGP; 1995.

89. Alberts WM, do Pico GA: Reactive airways dysfunction syndrome. Chest 1996, 109(6):1618-1626.
90. American Thoracic Society: Guidelines for assessing and managing asthma risk at work, school, and recreation. Am J Respir Crit Care Med 2004, 169(7):873-881.

91. Baur X, Degens $P$, Weber K: Occupational obstructive airway diseases in Germany. Am J Ind Med 1998, 33(5):454-462.

92. van Kampen $V$, Merget $R$, Baur X: Occupational airway sensitizers: an overview on the respective literature. Am J Ind Med 2000, 38(2):164-218

93. Webpage. http://www.hse.gov.uk

94. Malo JL: Irritant-induced asthma and reactive airways dysfunction syndrome. Can Respir J 1998, 5(1):66-67.

95. Malo JL, Chan-Yeung M: Asthma in the workplace: a Canadian contribution and perspective. Can Respir J 2007, 14(7):407-413

96. McDonald JC, Keynes HL, Meredith SK: Reported incidence of occupational asthma in the United Kingdom, 1989-97. Occup Environ Med 2000, 57(12):823-829.

97. Sastre J, Vandenplas O, Park HS: Pathogenesis of occupational asthma. Eur Respir J 2003, 22(2):364-373.

98. Joules H: Asthma from sensitisation to chromium. Lancet 1932, 2:182-183.

99. Boulet LP: Increases in airway responsiveness following acute exposure to respiratory irritants. Reactive airway dysfunction syndrome or occupational asthma? Chest 1988, 94(3):476-481.

100. Simonsson BG, Sjoberg A, Rolf C, Haeger-Aronsen B: Acute and long-term airway hyperreactivity in aluminium-salt exposed workers with nocturnal asthma. Eur J Respir Dis 1985, 66(2):105-118.

101. Matrat M, Laurence MF, Iwatsubo Y, Hubert C, Joly N, Legrand-Cattan K, L'Huillier JP, Villemain C, Pairon JC: Reactive airways dysfunction syndrome caused by bromochlorodifluoromethane from fire extinguishers. Occup Environ Med 2004, 61(8):712-714

102. Cone JE, Wugofski L, Balmes JR, Das R, Bowler R, Alexeeff G, Shusterman D: Persistent respiratory health effects after a metam sodium pesticide spill. Chest 1994, 106(2):500-508

103. Valero AL, Bescos $M$, Amat $P$, Malet A: Bronchial asthma caused by occupational sulfite exposure. Allergol Immunopathol (Madr) 1993, 21(6):221-224

104. Cockcroft DW, Hoeppner VH, Dolovich J: Occupational asthma caused by cedar urea formaldehyde particle board. Chest 1982, 82(1):49-53.

105. Hart JE, Laden F, Schenker MB, Garshick E: Chronic obstructive pulmonary disease mortality in diesel-exposed railroad workers. Environ Health Perspect 2006, 114(7):1013-1017.

106. Hart JE, Laden F, Eisen EA, Smith TJ, Garshick E: Chronic obstructive pulmonary disease mortality in railroad workers. Occup Environ Med 2009, 66(4):221-226

107. Ulvestad B, Lund MB: Increased risk of chronic obstructive pulmonary disease among tunnel construction workers. Tidsskr Nor Laegeforen 2003, 123(16):2292-2295.

108. Kern DG: Outbreak of the reactive airways dysfunction syndrome after a spill of glacial acetic acid. Am Rev Respir Dis 1991, 144(5):1058-1064.

109. Gamble J, Jones W, Hancock J, Meckstroth RL: Epidemiologicalenvironmental study of lead acid battery workers. III. Chronic effects of sulfuric acid on the respiratory system and teeth. Environ Res 1984, 35(1):30-52

110. Bohadana AB, Massin N, Wild P, Berthiot G: Airflow obstruction in chalkpowder and sugar workers. Int Arch Occup Environ Health 1996, 68(4):243-248

111. Mwaiselage J, Bratveit M, Moen BE, Mashalla Y: Respiratory symptoms and chronic obstructive pulmonary disease among cement factory workers. Scand J Work Environ Health 2005, 31(4):316-323.

112. Massin N, Hecht G, Ambroise D, Hery M, Toamain JP, Hubert G, Dorotte M, Bianchi B: Respiratory symptoms and bronchial responsiveness among cleaning and disinfecting workers in the food industry. Occup Environ Med 2007, 64(2):75-81.

113. Sprince NL, Oliver LC, Eisen EA, Greene RE, Chamberlin Rl: Cobalt exposure and lung disease in tungsten carbide production. A cross-sectional study of current workers. Am Rev Respir Dis 1988, 138(5):1220-1226

114. Woldeyohannes M, Bergevin Y, Mgeni AY, Theriault G: Respiratory problems among cotton textile mill workers in Ethiopia. $\mathrm{Br} J$ Ind Med 1991, 48(2):110-115. 
115. Rylander R, Bergstrom R: Bronchial reactivity among cotton workers in relation to dust and endotoxin exposure. Ann Occup Hyg 1993, 37(1):57-63

116. Rylander R, Haglind P, Lundholm M: Endotoxin in cotton dust and respiratory function decrement among cotton workers in an experimental cardroom. Am Rev Respir Dis 1985, 131(2):209-213.

117. Chen $R$, Tunstall-Pedoe $H$, Tavendale R: Environmental tobacco smoke and lung function in employees who never smoked: the Scottish MONICA study. Occup Environ Med 2001, 58(9):563-568.

118. Janson C, Chinn S, Jarvis D, Zock JP, Toren K, Burney P: Effect of passive smoking on respiratory symptoms, bronchial responsiveness, lung function, and total serum IgE in the European Community Respiratory Health Survey: a cross-sectional study. Lancet 2001, 358(9299):2103-2109.

119. Hoppin JA, Umbach DM, London SJ, Alavanja MC, Sandler DP: Diesel exhaust, solvents, and other occupational exposures as risk factors for wheeze among farmers. Am J Respir Crit Care Med 2004, 169(12):1308-1313.

120. Melenka LS, Hessel PA, Yoshida K, Enarson DA: Lung health in Alberta farmers. Int J Tuberc Lung Dis 1999, 3(10):913-919.

121. Ahman M, Alexandersson R, Ekholm U, Bergstrom B, Dahlqvist M, Ulfvarson $\mathrm{U}$ : Impeded lung function in moulders and coremakers handling furan resin sand. Int Arch Occup Environ Health 1991, 63(3):175-180.

122. Post W, Heederik D, Houba R: Decline in lung function related to exposure and selection processes among workers in the grain processing and animal feed industry. Occup Environ Med 1998, 55(5):349-355.

123. Schwartz DA, Thorne PS, Yagla SJ, Burmeister LF, Olenchock SA, Watt JL, Quinn TJ: The role of endotoxin in grain dust-induced lung disease. Am J Respir Crit Care Med 1995, 152(2):603-608.

124. Pahwa P, Senthilselvan A, McDuffie HH, Dosman JA: Longitudinal estimates of pulmonary function decline in grain workers. Am J Respir Crit Care Med 1994, 150(3):656-662.

125. Wisnewski AV, Liu Q, Liu J, Redlich CA: Glutathione protects human airway proteins and epithelial cells from isocyanates. Clin Exp Allergy 2005, 35(3):352-357.

126. Zock JP, Rodriguez-Trigo G, Pozo-Rodriguez F, Barbera JA, Bouso L, Torralba Y, Anto JM, Gomez FP, Fuster C, Verea H: Prolonged respiratory symptoms in clean-up workers of the prestige oil spill. Am J Respir Crit Care Med 2007, 176(6):610-616.

127. Wieslander G, Norback D, Edling C: Airway symptoms among house painters in relation to exposure to volatile organic compounds (VOCS)-a longitudinal study. Ann Occup Hyg 1997, 41(2):155-166.

128. Castro-Gutierrez N, McConnell R, Andersson K, Pacheco-Anton F, Hogstedt C: Respiratory symptoms, spirometry and chronic occupational paraquat exposure. Scand J Work Environ Health 1997, 23(6):421-427

129. Jones SM, Burks AW, Spencer HJ, Lensing S, Roberson PK, Gandy Helm RM: Occupational asthma symptoms and respiratory function among aerial pesticide applicators. Am J Ind Med 2003, 43(4):407-417.

130. Hagmar L, Bellander T, Ranstam J, Skerfving S: Piperazine-induced airway symptoms: exposure-response relationships and selection in an occupational setting. Am J Ind Med 1984, 6(5):347-357.

131. Calverley AE, Rees D, Dowdeswell RJ, Linnett PJ, Kielkowski D: Platinum salt sensitivity in refinery workers: incidence and effects of smoking and exposure. Occup Environ Med 1995, 52(10):661-666.

132. Lorimer W, Lilis R, Nicholson WJ, Anderson H, Fischbein A, Daum S, Rom W, Rice C, Selikoff IJ: Clinical studies of styrene workers: initial findings. Environ Health Perspect 1976, 17:171-181.

133. Prezant DJ, Weiden M, Banauch Gl, McGuinness G, Rom WN, Aldrich TK, Kelly KJ: Cough and bronchial responsiveness in firefighters at the World Trade Center site. N Engl J Med 2002, 347(11):806-815.

134. Jaakkola MS, Leino T, Tammilehto L, Ylostalo P, Kuosma E, Alanko K Respiratory effects of exposure to methacrylates among dental assistants. Allergy 2007, 62(6):648-654.

135. Medina-Ramon M, Zock JP, Kogevinas M, Sunyer J, Torralba Y, Borrell A, Burgos F, Anto JM: Asthma, chronic bronchitis, and exposure to irritant agents in occupational domestic cleaning: a nested case-control study. Occup Environ Med 2005, 62(9):598-606.

136. Sauni R, Oksa P, Huikko S, Roto P, Uitti J: Increased risk of asthma among Finnish construction workers. Occup Med (Lond) 2003, 53(8):527-531.
137. Jaakkola MS, Piipari R, Jaakkola N, Jaakkola JJ: Environmental tobacco smoke and adult-onset asthma: a population-based incident casecontrol study. Am J Public Health 2003, 93(12):2055-2060.

138. Greer JR, Abbey DE, Burchette RJ: Asthma related to occupational and ambient air pollutants in nonsmokers. J Occup Med 1993, 35(9):909-915

139. Eisner MD, Balmes J, Katz PP, Trupin L, Yelin EH, Blanc PD: Lifetime environmental tobacco smoke exposure and the risk of chronic obstructive pulmonary disease. Environ Health 2005, 4(1):7.

140. Fidan F, Cimrin AH, Ergor G, Sevinc C: Airway disease risk from environmental tobacco smoke among coffeehouse workers in Turkey. Tob Control 2004, 13(2):161-166.

141. Radon K, Busching K, Heinrich J, Wichmann HE, Jorres RA, Magnussen H, Nowak D: Passive smoking exposure: a risk factor for chronic bronchitis and asthma in adults? Chest 2002, 122(3):1086-1090

142. Blanc PD, Ellbjar S, Janson C, Norback D, Norrman E, Plaschke P, Toren K: Asthma-related work disability in Sweden. The impact of workplace exposures. Am J Respir Crit Care Med 1999, 160(6):2028-2033.

143. Flodin U, Jonsson P, Ziegler J, Axelson O: An epidemiologic study of bronchial asthma and smoking. Epidemiology 1995, 6(5):503-505.

144. Eduard W, Douwes J, Omenaas E, Heederik D: Do farming exposures cause or prevent asthma? Results from a study of adult Norwegian farmers. Thorax 2004, 59(5):381-386.

145. Hoppin JA, Umbach DM, London SJ, Alavanja MC, Sandler DP: Animal production and wheeze in the Agricultural Health Study: interactions with atopy, asthma, and smoking. Occup Environ Med 2003, 60(8):e3.

146. Melbostad E, Eduard W, Magnus P: Determinants of asthma in a farming population. Scand J Work Environ Health 1998, 24(4):262-269.

147. Mastrangelo G, Tartari M, Fedeli U, Fadda E, Saia B: Ascertaining the risk of chronic obstructive pulmonary disease in relation to occupation using a case-control design. Occup Med (Lond) 2003, 53(3):165-172.

148. Mastrangelo G, Paruzzolo P, Mapp C: Asthma due to isocyanates: a mail survey in a $1 \%$ sample of furniture workers in the Veneto region, Italy. Med Lav 1995, 86(6):503-510.

149. Meredith SK, Bugler J, Clark RL: Isocyanate exposure and occupational asthma: a case-referent study. Occup Environ Med 2000, 57(12):830-836.

150. Jacobs JH, Spaan S, van Rooy GB, Meliefste C, Zaat VA, Rooyackers JM, Heederik D: Exposure to trichloramine and respiratory symptoms in indoor swimming pool workers. Eur Respir J 2007, 29(4):690-698.

151. Schenker MB, Stoecklin M, Lee K, Lupercio R, Zeballos RJ, Enright P, Hennessy T, Beckett LA: Pulmonary function and exercise-associated changes with chronic low-level paraquat exposure. Am J Respir Crit Care Med 2004, 170(7):773-779.

152. Senthilselvan A, McDuffie HH, Dosman JA: Association of asthma with use of pesticides. Results of a cross-sectional survey of farmers. Am Rev Respir Dis 1992, 146(4):884-887

153. Danuser B, Weber C, Kunzli N, Schindler C, Nowak D: Respiratory symptoms in Swiss farmers: an epidemiological study of risk factors. Am J Ind Med 2001, 39(4):410-418.

154. Andersson E, Nilsson T, Persson B, Wingren G, Toren K: Mortality from asthma and cancer among sulfite mill workers. Scand J Work Environ Health 1998, 24(1):12-17.

155. Preller L, Heederik D, Boleij JS, Vogelzang PF, Tielen MJ: Lung function and chronic respiratory symptoms of pig farmers: focus on exposure to endotoxins and ammonia and use of disinfectants. Occup Environ Med 1995, 52(10):654-660.

156. Wheeler K, McKelvey W, Thorpe L, Perrin M, Cone J, Kass D, Farfel M, Thomas P, Brackbill R: Asthma diagnosed after 11 September 2001 among rescue and recovery workers: findings from the World Trade Center Health Registry. Environ Health Perspect 2007, 115(11):1584-1590.

157. Rajan KG, Davies BH: Reversible airways obstruction and interstitial pneumonitis due to acetic acid. Br J Ind Med 1989, 46(1):67-68

158. Kivity S, Fireman E, Lerman Y: Late asthmatic response to inhaled glacial acetic acid. Thorax 1994, 49(7):727-728.

159. Moore VC, Manney S, Vellore AD, Burge PS: Occupational asthma to gel flux containing dodecanedioic acid. Allergy 2009, 64(7):1099-1100.

160. Musk AW, Peach S, Ryan G: Occupational asthma in a mineral analysis laboratory. Br J Ind Med 1988, 45(6):381-386 
161. Deschamps D, Soler P, Rosenberg N, Baud F, Gervais P: Persistent asthma after inhalation of a mixture of sodium hypochlorite and hydrochloric acid. Chest 1994, 105(6):1895-1896.

162. Promisloff RA, Lenchner GS, Phan A, Cichelli AV: Reactive airway dysfunction syndrome in three police officers following a roadside chemical spill. Chest 1990, 98(4):928-929.

163. Franzblau A, Sahakian N: Asthma following household exposure to hydrofluoric acid. Am J Ind Med 2003, 44(3):321-324.

164. el-Sadik YM, Osman HA, el-Gazzar RM: Exposure to sulfuric acid in manufacture of storage batteries. J Occup Med 1972, 14(3):224-226.

165. Chatkin JM, Tarlo SM, Liss G, Banks D, Broder I: The outcome of asthma related to workplace irritant exposures: a comparison of irritant-induced asthma and irritant aggravation of asthma. Chest 1999, 116(6):1780-1785.

166. Savonius B, Keskinen $H$, Tuppurainen M, Kanerva L: Occupational respiratory disease caused by acrylates. Clin Exp Allergy 1993, 23(5):416-424

167. Yacoub MR, Lemiere C, Malo JL: Asthma caused by cyanoacrylate used in a leisure activity. J Allergy Clin Immunol 2005, 116(2):462

168. Nakazawa T: Occupational asthma due to alkyl cyanoacrylate. J Occup Med 1990, 32(8):709-710.

169. Lozewicz S, Davison AG, Hopkirk A, Burge PS, Boldy DA, Riordan JF, McGivern DV, Platts BW, Davies D, Newman Taylor AJ: Occupational asthma due to methyl methacrylate and cyanoacrylates. Thorax 1985, 40(11):836-839.

170. Chan CC, Cheong TH, Lee HS, Wang YT, Poh SC: Case of occupational asthma due to glue containing cyanoacrylate. Ann Acad Med Singapore 1994, 23(5):731-733.

171. Quirce S, Baeza ML, Tornero P, Blasco A, Barranco R, Sastre J: Occupational asthma caused by exposure to cyanoacrylate. Allergy 2001, 56(5):446-449.

172. Kopp SK, McKay RT, Moller DR, Cassedy K, Brooks SM: Asthma and rhinitis due to ethylcyanoacrylate instant glue. Ann Intern Med 1985, 102(5):613-615.

173. Weytjens K, Cartier A, Lemiere C, Malo JL: Occupational asthma to diacrylate. Allergy 1999, 54(3):289-290

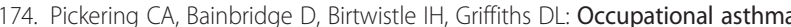
due to methyl methacrylate in an orthopaedic theatre sister. $\mathrm{Br}$ Med $J$ (Clin Res Ed) 1986, 292(6532):1362-1363.

175. Savonius B, Keskinen H, Tuppurainen M, Kanerva L: Occupational asthma caused by ethanolamines. Allergy 1994, 49(10):877-881.

176. Pepys J, Pickering CA: Asthma due to inhaled chemical fumes-aminoethyl ethanolamine in aluminium soldering flux. Clin Allergy 1972, 2(2):197-204.

177. Hnizdo E, Sylvain D, Lewis DM, Pechter E, Kreiss K: New-onset asthma associated with exposure to 3-amino-5-mercapto-1,2,4-triazole. J Occup Environ Med 2004, 46(12):1246-1252.

178. Ali BA, Ahmed HO, Ballal SG, Albar AA: Pulmonary function of workers exposed to ammonia: a study in the Eastern Province of Saudi Arabia. Int J Occup Environ Health 2001, 7(1):19-22.

179. Bernstein DI: Guidelines for the diagnosis and evaluation of occupational immunologic lung disease. St. Louis: Mosby Co; 1989.

180. de la Hoz RE, Schlueter DP, Rom WN: Chronic lung disease secondary to ammonia inhalation injury: a report on three cases. Am J Ind Med 1996, 29(2):209-214

181. Leduc D, Gris P, Lheureux P, Gevenois PA, De Vuyst P, Yernault JC: Acute and long term respiratory damage following inhalation of ammonia. Thorax 1992, 47(9):755-757.

182. Flury KE, Dines DE, Rodarte JR, Rodgers R: Airway obstruction due to inhalation of ammonia. Mayo Clin Proc 1983, 58(6):389-393.

183. Weir DC, Robertson AS, Jones S, Burge PS: Occupational asthma due to soft corrosive soldering fluxes containing zinc chloride and ammonium chloride. Thorax 1989, 44(3):220-223.

184. Gelfand HH: Respiratory Allergy Due to Chemical Compounds Encountered in the Rubber, Lacquer, Shellac, and Beauty Culture Industries. J Allergy Clin Immunol 1963, 34:374-381.

185. Greene SA, Freedman S: Asthma due to inhaled chemical agentsamprolium hydrochloride. Clin Allergy 1976, 6(2):105-108.

186. Baur X, Czuppon AB, Rauluk I, Zimmermann FB, Schmitt B, Egen-Korthaus M, Tenkhoff N, Degens PO: A clinical and immunological study on 92 workers occupationally exposed to anhydrides. Int Arch Occup Environ Health 1995, 67(6):395-403.

187. Drexler H, Weber A, Letzel S, Kraus G, Schaller KH, Lenhert G: Detection and clinical relevance of a type I allergy with occupational exposure to hexahydrophthalic anhydride and methyltetrahydrophthalic anhydride. Int Arch Occup Environ Health 1994, 65(5):279-283.

188. Cipolla C, Belisario A, Sassi C, Auletti G, Nobile M, Raffi GB: Occupational asthma caused by dioctyl-phthalate in a bottle cap production worker. Med Lav 1999, 90(3):513-518.

189. Chee CB, Lee HS, Cheong TH, Wang YT, Poh SC: Occupational asthma due to hexahydrophthalic anhydride: a case report. $\mathrm{Br} J$ Ind Med 1991, 48(9):643-645.

190. Rosenman KD, Bernstein DI, O'Leary K, Gallagher JS, D'Souza L, Bernstein IL: Occupational asthma caused by himic anhydride. Scand J Work Environ Health 1987, 13(2):150-154

191. Lee HS, Wang YT, Cheong TH, Tan KT, Chee BE, Narendran K: Occupational asthma due to maleic anhydride. $\mathrm{Br} J$ Ind Med 1991, 48(4):283-285

192. Graneek BJ, Durham SR, Newman Taylor AJ: Late asthmatic reactions and changes in histamine responsiveness provoked by occupational agents Bull Eur Physiopathol Respir 1987, 23(6):577-581.

193. Nielsen J, Welinder H, Skerfving S: Allergic airway disease caused by methyl tetrahydrophthalic anhydride in epoxy resin. Scand J Work Environ Health 1989, 15(2):154-155

194. Nielsen J, Welinder H, Schutz A, Skerfving S: Specific serum antibodies against phthalic anhydride in occupationally exposed subjects. J Allergy Clin Immunol 1988, 82(1):126-133.

195. Wernfors M, Nielsen J, Schutz A, Skerfving S: Phthalic anhydride-induced occupational asthma. Int Arch Allergy Appl Immunol 1986, 79(1):77-82.

196. Frans A, Pahulycz C: Transient syndrome of acute irritation of the bronchi induced by single and massive inhalation of phthalic anhydride. Rev Pneumol Clin 1993, 49(5):247-251.

197. Fawcett IW, Taylor AJ, Pepys J: Asthma due to inhaled chemical agentsepoxy resin systems containing phthalic acid anhydride, trimellitic acid anhydride and triethylene tetramine. Clin Allergy 1977, 7(1):1-14.

198. Maccia CA, Bernstein IL, Emmett EA, Brooks SM: In vitro demonstration of specific lgE in phthalic anhydride hypersensitivity. Am Rev Respir Dis 1976, 113(5):701-704.

199. Meadway J: Asthma and atopy in workers with an epoxy adhesive. $\mathrm{Br} J$ Dis Chest 1980, 74(2):149-154

200. Venables KM, Topping MD, Howe W, Luczynska CM, Hawkins R, Taylor AJ: Interaction of smoking and atopy in producing specific lgE antibody against a hapten protein conjugate. Br Med J (Clin Res Ed) 1985, 290(6463):201-204

201. Venables KM, Topping MD, Nunn AJ, Howe W, Newman Taylor AJ: Immunologic and functional consequences of chemical (tetrachlorophthalic anhydride)-induced asthma after four years of avoidance of exposure. J Allergy Clin Immunol 1987, $80(2): 212-218$

202. Howe W, Venables KM, Topping MD, Dally MB, Hawkins R, Law JS, Taylor AJ: Tetrachlorophthalic anhydride asthma: evidence for specific $\lg \mathrm{E}$ antibody. J Allergy Clin Immunol 1983, 71(1 Pt 1):5-11.

203. Schlueter DP, Banaszak EF, Fink JN, Barboriak J: Occupational asthma due to tetrachlorophthalic anhydride. J Occup Med 1978, 20(3):183-188.

204. Grammer LC, Shaughnessy MA, Kenamore BD: Clinical and immunologic outcome of 42 individuals with trimellitic anhydride-induced immunologic lung disease after transfer to low exposure. Allergy Asthma Proc 2000, 21(6):355-359.

205. Grammer LC, Shaughnessy MA, Kenamore BD, Yarnold PR: A clinical and immunologic study to assess risk of TMA-induced lung disease as related to exposure. J Occup Environ Med 1999, 41(12):1048-1051.

206. Grammer L, Shaughnessy M, Kenamore B: Utility of antibody in identifying individuals who have or will develop anhydride-induced respiratory disease. Chest 1998, 114(4):1199-1202.

207. Zeiss CR, Patterson R, Pruzansky JJ, Miller MM, Rosenberg M, Levitz D: Trimellitic anhydride-induced airway syndromes: clinical and immunologic studies. J Allergy Clin Immunol 1977, 60(2):96-103.

208. Kanerva L, Keskinen H, Autio P, Estlander T, Tuppurainen M, Jolanki R: Occupational respiratory and skin sensitization caused by polyfunctional aziridine hardener. Clin Exp Allergy 1995, 25(5):432-439. 
209. Leffler CT, Milton DK: Occupational asthma and contact dermatitis in a spray painter after introduction of an aziridine cross-linker. Environ Health Perspect 1999, 107(7):599-601.

210. Slovak AJ: Occupational asthma caused by a plastics blowing agent, azodicarbonamide. Thorax 1981, 36(12):906-909

211. Kim CW, Cho JH, Leem JH, Ryu JS, Lee HL, Hong YC: Occupational asthma due to azodicarbonamide. Yonsei Med J 2004, 45(2):325-329.

212. Normand JC, Grange F, Hernandez C, Ganay A, Davezies P, Bergeret A, Prost G: Occupational asthma after exposure to azodicarbonamide: report of four cases. Br J Ind Med 1989, 46(1):60-62.

213. Valentino $M$, Comai M: Occupational asthma caused by azodicarbonamide: clinical case. G Ital Med Lav 1985, 7(2-3):97-99.

214. Malo JL, Pineau L, Cartier A: Occupational asthma due to azobisformamide. Clin Allergy 1985, 15(3):261-264.

215. Purohit A, Kopferschmitt-Kubler MC, Moreau C, Popin E, Blaumeiser M, Pauli G: Quaternary ammonium compounds and occupational asthma. Int Arch Occup Environ Health 2000, 73(6):423-427.

216. Bernstein JA, Stauder T, Bernstein DI, Bernstein IL: A combined respiratory and cutaneous hypersensitivity syndrome induced by work exposure to quaternary amines. J Allergy Clin Immunol 1994, 94(2 Pt 1):257-259.

217. Moscato G, Omodeo P, Dellabianca A, Colli MC, Pugliese F, Locatelli C, Scibilia J: Occupational asthma and rhinitis caused by 1,2benzisothiazolin-3-one in a chemical worker. Occup Med (Lond) 1997, 47(4):249-251

218. Burns MJ, Linden $\mathrm{CH}$ : Another hot tub hazard. Toxicity secondary to bromine and hydrobromic acid exposure. Chest 1997, 111(3):816-819.

219. de la Hoz RE: Reactive airways dysfunction syndrome following exposure to a fluorocarbon. Eur Respir J 1999, 13(5):1192-1194.

220. Chan OY, Poh SC, Lee HS, Tan KT, Kwok SF: Respiratory function in cadmium battery workers-a follow-up study. Ann Acad Med Singapore 1988, 17(2):283-287.

221. Leduc $D$, de Francquen $P$, Jacobovitz $D$, Vandeweyer $R$, Lauwerys $R$, $D e$ Vuyst P: Association of cadmium exposure with rapidly progressive emphysema in a smoker. Thorax 1993, 48(5):570-571.

222. De Silva PE, Donnan MB: Chronic cadmium poisoning in a pigment manufacturing plant. $\mathrm{Br} J$ Ind Med 1981, 38(1):76-86.

223. Royce S, Wald P, Sheppard D, Balmes J: Occupational asthma in a pesticides manufacturing worker. Chest 1993 103(1):295-296.

224. Neghab M, Mohraz MH, Hassanzadeh J: Symptoms of respiratory disease and lung functional impairment associated with occupational inhalation exposure to carbon black dust. J Occup Health 2011, 53(6):432-438

225. Bourne MS, Flindt ML, Walker JM: Asthma due to industrial use of chloramine. BMJ 1979, 2(6181):10-12

226. Feinberg SM, Watrons RM: Atopy to simple chemical compoundssulfonechloramides. J Allergy Clin Immunol 1945, 16(5):209-220.

227. Kujala VM, Reijula KE, Ruotsalainen EM, Heikkinen K: Occupational asthma due to chloramine-T solution. Respir Med 1995, 89(10):693-695.

228. Jouannique V, Pillière F, Pouillard D, Gervais $P$, Rousselin X, Efthymiou ML: Asthme professionel à la chloramine $\mathrm{T}$. In A propos de deux observations. Paris: Société De Médicine et d'Hygiène du Travail; 1992:654-657.

229. Dijkman JH, Vooren PH, Kramps JA: Occupational asthma due to inhalation of chloramine-T. I. Clinical observations and inhalationprovocation studies. Int Arch Allergy Appl Immunol 1981, 64(4):422-427.

230. Waclawski ER, McAlpine LG, Thomson NC: Occupational asthma in nurses caused by chlorhexidine and alcohol aerosols. Bmj 1989, 298(6678):929-930.

231. Glindmeyer HW, Lefante JJ, Freyder LM, Friedman M, Weill H, Jones RN: Relationship of asthma to irritant gas exposures in pulp and paper mills. Respir Med 2003, 97(5):541-548.

232. Andersson E, Olin AC, Hagberg S, Nilsson R, Nilsson T, Toren K: Adult-onset asthma and wheeze among irritant-exposed bleachery workers. Am J Ind Med 2003, 43(5):532-538.

233. Gautrin D, Leroyer C, L'Archeveque J, Dufour JG, Girard D, Malo JL: Crosssectional assessment of workers with repeated exposure to chlorine over a three year period. Eur Respir J 1995, 8(12):2046-2054.

234. Bherer L, Cushman R, Courteau JP, Quevillon M, Cote G, Bourbeau J, L'Archeveque J, Cartier A, Malo JL: Survey of construction workers repeatedly exposed to chlorine over a three to six month period in a pulpmill: II. Follow up of affected workers by questionnaire, spirometry, and assessment of bronchial responsiveness 18 to 24 months after exposure ended. Occup Environ Med 1994, 51(4):225-228.

235. Leroyer C, Dewitte JD, Bassanets A, Boutoux M, Daniel C, Clavier J: Occupational asthma due to chromium. Respiration 1998, 65(5):403-405

236. Chester EH, Gillespie DG, Krause FD: The prevalence of chronic obstructive pulmonary disease in chlorine gas workers. Am Rev Respir Dis 1969, 99(3):365-373.

237. Ferris BG Jr, Burgess WA, Worcester J: Prevalence of chronic respiratory disease in a pulp mill and a paper mill in the United States. Br J Ind Med 1967, 24(1):26-37.

238. Lemiere C, Malo JL, Boutet M: Reactive airways dysfunction syndrome due to chlorine: sequential bronchial biopsies and functional assessment. Eur Respir J 1997, 10(1):241-244.

239. Schonhofer B, Voshaar T, Kohler D: Long-term lung sequelae following accidental chlorine gas exposure. Respiration 1996, 63(3):155-159.

240. Olaguibel JM, Basomba A: Occupational asthma induced by chromium salts. Allergol Immunopathol (Madr) 1989, 17(3):133-136.

241. Onizuka R, Tanabe K, Nakayama Y, Fukuchi T, Nakata K, Hiki T: A case of chrome asthma induced by exposure to the stone cutter dust. Arerugi 2006, 55(12):1556-1561.

242. Fernandez-Nieto M, Quirce S, Carnes J, Sastre J: Occupational asthma due to chromium and nickel salts. Int Arch Occup Environ Health 2006, 79(6):483-486

243. Sastre J, Fernandez-Nieto M, Maranon F, Fernandez-Caldas E, Pelta R, Quirce S: Allergenic cross-reactivity between nickel and chromium salts in electroplating-induced asthma. J Allergy Clin Immunol 2001, 108(4):650-651.

244. Nagasaka Y, Nakano N, Tohda Y, Nakajima S: Persistent reactive airway dysfunction syndrome after exposure to chromate]. Nihon Kyobu Shikkan Gakkai Zasshi 1995, 33(7):759-764

245. Park HS, Yu HJ, Jung KS: Occupational asthma caused by chromium. Clin Exp Allergy 1994, 24(7):676-681.

246. Novey HS, Habib M, Wells ID: Asthma and IgE antibodies induced by chromium and nickel salts. J Allergy Clin Immunol 1983, 72(4):407-412.

247. Bernstein IL, Merget R: Metals. In Asthma in the workplace. 3rd edition. Edited by Bernstein IL, Chan-Yeung M, Malo JL, Bernstein DI. New York: Taylor \& Francis; 2006:525-554.

248. Linna A, Oksa P, Palmroos P, Roto P, Laippala P, Uitti J: Respiratory health of cobalt production workers. Am J Ind Med 2003, 44(2):124-132.

249. Kusaka Y, Iki M, Kumagai S, Goto S: Epidemiological study of hard metal asthma. Occup Environ Med 1996, 53(3):188-193.

250. Kennedy SM, Chan-Yeung M, Marion S, Lea J, Teschke K: Maintenance of stellite and tungsten carbide saw tips: respiratory health and exposureresponse evaluations. Occup Environ Med 1995, 52(3):185-191.

251. Roto P: Asthma, symptoms of chronic bronchitis and ventilatory capacity among cobalt and zinc production workers. Scand J Work Environ Health 1980, 6(Suppl 1):1-49.

252. Pisati G, Zedda S: Outcome of occupational asthma due to cobalt hypersensitivity. Sci Total Environ 1994, 150(1-3):167-171.

253. Shirakawa T, Kusaka Y, Fujimura N, Goto S, Kato M, Heki S, Morimoto K: Occupational asthma from cobalt sensitivity in workers exposed to hard metal dust. Chest 1989, 95(1):29-37.

254. Shirakawa T, Kusaka Y, Fujimura N, Goto S, Morimoto K: The existence of specific antibodies to cobalt in hard metal asthma. Clin Allergy 1988 18(5):451-460

255. Shirakawa T, Kusaka Y, Fujimura N, Kato M, Heki S, Morimoto K: Hard metal asthma: cross immunological and respiratory reactivity between cobalt and nickel? Thorax 1990, 45(4):267-271.

256. Gheysens B, Auwerx J, Van den Eeckhout A, Demedts M: Cobalt-induced bronchial asthma in diamond polishers. Chest 1985, 88(5):740-744.

257. Baik JJ, Yoon YB, Park HS: Cobalt-induced occupational asthma associated with systemic illness. J Korean Med Sci 1995, 10(3):200-204.

258. Wilk-Rivard E, Szeinuk J: Occupational asthma with paroxysmal atrial fibrillation in a diamond polisher. Environ Health Perspect 2001, 109(12):1303-1306.

259. Krakowiak A, Dudek W, Tarkowski M, Swiderska-Kielbik S, Niescierenko E, Palczynski C: Occupational asthma caused by cobalt chloride in a diamond polisher after cessation of occupational exposure: a case report. Int J Occup Med Environ Health 2005, 18(2):151-158. 
260. Sargent EV, Brubaker RE, Mitchell CA: Respiratory effects of occupational exposure to an epoxy resin system. Arch Environ Health 1976, 31(5):236-240.

261. Aleva RM, Aalbers R, Koeter GH, De Monchy JG: Occupational asthma caused by a hardener containing an aliphatic and a cycloaliphatic diamine. Am Rev Respir Dis 1992, 145(5):1217-1218,

262. Luczynska CM, Hutchcroft BJ, Harrison MA, Dornan JD, Topping MD: Occupational asthma and specific lgE to a diazonium salt intermediate used in the polymer industry. J Allergy Clin Immunol 1990, 85(6):1076-1082.

263. Graham VA, Coe MJ, Davies RJ: Occupational asthma after exposure to a diazonium salt. Thorax 1981, 36(12):950-951.

264. Emad A, Rezaian GR: The diversity of the effects of sulfur mustard gas inhalation on respiratory system 10 years after a single, heavy exposure: analysis of 197 cases. Chest 1997, 112(3):734-738.

265. Deschamps D, Questel F, Baud FJ, Gervais P, Dally S: Persistent asthma after acute inhalation of organophosphate insecticide. Lancet 1994, 344(8938):1712.

266. Barthel E: Irritative and allergic effects of pesticide aerosols on the respiratory tract and problems of their evaluation. Z Gesamte Hyg 1983, 29(11):678-681.

267. Piipari R, Tuppurainen M, Tuomi T, Mantyla L, Henriks-Eckerman ML, Keskinen $\mathrm{H}$, Nordman H: Diethanolamine-induced occupational asthma, a case report. Clin Exp Allergy 1998, 28(3):358-362.

268. Gadon ME, Melius JM, McDonald GJ, Orgel D: New-onset asthma after exposure to the steam system additive 2-diethylaminoethanol. A descriptive study. J Occup Med 1994, 36(6):623-626.

269. Vallieres M, Cockcroft DW, Taylor DM, Dolovich J, Hargreave FE: Dimethyl ethanolamine-induced asthma. Am Rev Respir Dis 1977, 115(5):867-871.

270. Cockcroft DW, Cotton DJ, Mink JT: Nonspecific bronchial hyperreactivity after exposure to Western Red Cedar. Am Rev Respir Dis 1979, 119(3):505-510.

271. Conrad E, Lo W, de Boisblanc BP, Shellito JE: Reactive airways dysfunction syndrome after exposure to dinitrogen tetroxide. South Med J 1998, 91(4):338-341

272. Aldrich FD, Stange AW, Geesaman RE: Smoking and ethylene diamine sensitization in an industrial population. J Occup Med 1987, 29(4):311-314.

273. Casas X, Badorrey I, Monso E, Morera J: Occupational asthma due to amines]. Arch Bronconeumol 2002, 38(2):93-94

274. Hagmar L, Bellander T, Bergoo B, Simonsson BG: Piperazine-induced occupational asthma. J Occup Med 1982, 24(3):193-197.

275. Lam S, Chan-Yeung M: Ethylenediamine-induced asthma. Am Rev Respir Dis 1980, 121(1):151-155

276. Deschamps D, Rosenberg N, Soler P, Maillard G, Fournier E, Salson D, Gervais P: Persistent asthma after accidental exposure to ethylene oxide. Br J Ind Med 1992, 49(7):523-525.

277. Duque P, Faraut C, Figueredo M, Bettendorf A, Salvadori JM: Occupational asthma provoked by ethylene oxide in a nurse. Presse Med 1991 20(30):1455.

278. Nunn AJ, Craigen AA, Darbyshire JH, Venables KM, Newman Taylor AJ: Six year follow up of lung function in men occupationally exposed to formaldehyde. Br J Ind Med 1990, 47(11):747-752.

279. Nordman $\mathrm{H}$, Keskinen $\mathrm{H}$, Tuppurainen M: Formaldehyde asthma-rare or overlooked? J Allergy Clin Immunol 1985, 75(1 Pt 1):91-99.

280. Burge PS, Harries MG, Lam WK, O'Brien IM, Patchett PA: Occupational asthma due to formaldehyde. Thorax 1985, 40(4):255-260.

281. Piipari R, Keskinen H: Agents causing occupational asthma in Finland in 1986-2002: cow epithelium bypassed by moulds from moisturedamaged buildings. Clin Exp Allergy 2005, 35(12):1632-1637.

282. Kim CW, Song JS, Ahn YS, Park SH, Park JW, Noh JH, Hong CS: Occupational asthma due to formaldehyde. Yonsei Med J 2001, 42(4):440-445.

283. Lemiere C, Desjardins A, Cloutier Y, Drolet D, Perrault G, Cartier A, Malo JL: Occupational asthma due to formaldehyde resin dust with and without reaction to formaldehyde gas. Eur Respir 」 1995, 8(5):861-865.

284. Porter JA: Letter: Acute respiratory distress following formalin inhalation. Lancet 1975, 2(7935):603-604

285. Hendrick DJ, Lane DJ: Formalin asthma in hospital staff. BMJ 1975, 1(5958):607-608

286. Sjogren B, Gunnare S, Sandler H: Inhalation of decomposed chlorodifluoromethane (freon-22) and myocardial infarction. Scand J Work Environ Health 2002, 28(3):205-207.
287. Malo JL, Gagnon G, Cartier A: Occupational asthma due to heated freon. Thorax 1984, 39(8):628-629.

288. Vyas A, Pickering CA, Oldham LA, Francis HC, Fletcher AM, Merrett T, Niven RM: Survey of symptoms, respiratory function, and immunology and their relation to glutaraldehyde and other occupational exposures among endoscopy nursing staff. Occup Environ Med 2000, 57(11):752-759.

289. Curran AD, Burge PS, Wiley K: Clinical and immunologic evaluation of workers exposed to glutaraldehyde. Allergy 1996, 51(11):826-832

290. Gannon PF, Bright P, Campbell M, O'Hickey SP, Burge PS: Occupational asthma due to glutaraldehyde and formaldehyde in endoscopy and $x$ ray departments. Thorax 1995, 50(2):156-159.

291. Jachuck SJ, Bound CL, Steel J, Blain PG: Occupational hazard in hospital staff exposed to 2 per cent glutaraldehyde in an endoscopy unit. J Soc Occup Med 1989, 39(2):69-71.

292. Ong TH, Tan KL, Lee HS, Eng P: A case report of occupational asthma due to gluteraldehyde exposure. Ann Acad Med Singapore 2004, 33(2):275-278.

293. Cullinan P, Hayes J, Cannon J, Madan I, Heap D, Taylor AN: Occupational asthma in radiographers. Lancet 1992, 340(8833):1477.

294. Corrado OJ, Osman J, Davies RJ: Asthma and rhinitis after exposure to glutaraldehyde in endoscopy units. Hum Toxicol 1986, 5(5):325-328.

295. Nagy L, Orosz M: Occupational asthma due to hexachlorophene. Thorax 1984, 39(8):630-631.

296. Merget R, Topcu M, Friese K, Vormberg R, Fuchs T, Raulf-Heimsoth M, Breitstadt R: A cross-sectional study of workers in the chemical industry with occupational exposure to hexamethylenetetramine. Int Arch Occup Environ Health 1999, 72(8):533-538.

297. Gamble JF, McMichael AJ, Williams T, Battigelli M: Respiratory function and symptoms: an environmental-epidemiological study of rubber workers exposed to a phenolformaldehyde type resin. Am Ind Hyg Assoc J 1976, 37(9):499-513

298. Bergman A, Svedberg U, Nilsson E: Contact urticaria with anaphylactic reactions caused by occupational exposure to iridium salt. Contact Dermatitis 1995, 32(1):14-17.

299. Baur X, Dewair M, Fruhmann G: Detection of immunologically sensitized isocyanate workers by RAST and intracutaneous skin tests. J Allergy Clin Immunol 1984, 73(5 Pt 1):610-618.

300. Piirila PL, Nordman H, Keskinen HM, Luukkonen R, Salo SP, Tuomi TO, Tuppurainen M: Long-term follow-up of hexamethylene diisocyanatediphenylmethane diisocyanate-, and toluene diisocyanate-induced asthma. Am J Respir Crit Care Med 2000, 162(2 Pt 1):516-522

301. O'Brien IM, Harries MG, Burge PS, Pepys J: Toluene di-isocyanate-induced asthma. I. Reactions to TDI, MDI, HDI and histamine. Clin Allergy 1979, 9(1):1-6.

302. Cartier A, Grammer L, Malo JL, Lagier F, Ghezzo H, Harris K, Patterson R: Specific serum antibodies against isocyanates: association with occupational asthma. J Allergy Clin Immunol 1989, 84(4 Pt 1):507-514.

303. Tarlo SM, Liss GM, Yeung KS: Changes in rates and severity of compensation claims for asthma due to diisocyanates: a possible effect of medical surveillance measures. Occup Environ Med 2002, 59(1):58-62.

304. Bernstein DI, Korbee L, Stauder T, Bernstein JA, Scinto J, Herd ZL, Bernstein IL: The low prevalence of occupational asthma and antibody-dependent sensitization to diphenylmethane diisocyanate in a plant engineered for minimal exposure to diisocyanates. J Allergy Clin Immunol 1993, 92(3):387-396

305. Liss GM, Bernstein DI, Moller DR, Gallagher JS, Stephenson RL, Bernstein IL: Pulmonary and immunologic evaluation of foundry workers exposed to methylene diphenyldiisocyanate (MDI). J Allergy Clin Immunol 1988, 82(1):55-61.

306. Woellner RC, Hall S, Greaves I, Schoenwetter WF: Epidemic of asthma in a wood products plant using methylene diphenyl diisocyanate. Am J Ind Med 1997, 31(1):56-63.

307. Mapp CE, Corona PC, De Marzo N, Fabbri L: Persistent asthma due to isocyanates. A follow-up study of subjects with occupational asthma due to toluene diisocyanate (TDI). Am Rev Respir Dis 1988, 137(6):1326-1329.

308. Zammit-Tabona M, Sherkin M, Kijek K, Chan H, Chan-Yeung M: Asthma caused by diphenylmethane diisocyanate in foundry workers. Clinical, bronchial provocation, and immunologic studies. Am Rev Respir Dis 1983, 128(2):226-230. 
309. Perfetti L, Brame B, Ferrari M, Moscato G: Occupational asthma (OA) with sensitization to diphenylmethane diisocyanate (MDI) presenting at the onset like a reactive airways dysfunction syndrome (RADS). Am J Ind Med 2003, 44(3):325-328.

310. Hur GY, Koh DH, Choi GS, Park HJ, Choi SJ, Ye YM, Kim KS, Park HS: Clinical and immunologic findings of methylene diphenyl diisocyanate-induced occupational asthma in a car upholstery factory. Clin Exp Allergy 2008, 38(4):586-593.

311. Vandenplas O, Malo JL, Dugas M, Cartier A, Desjardins A, Levesque J, Shaughnessy MA, Grammer LC: Hypersensitivity pneumonitis-like reaction among workers exposed to diphenylmethane [correction to piphenylmethane] diisocyanate (MDI). Am Rev Respir Dis 1993, 147(2):338-346.

312. Lemiere $C$, Malo $J$, Boulet $L P$, Boutet M: Reactive airways dysfunction syndrome induced by exposure to a mixture containing isocyanate: functional and histopathologic behaviour. Allergy 1996, 51(4):262-265.

313. Belin L, Hjortsberg U, Wass U: Life-threatening pulmonary reaction to car paint containing a prepolymerized isocyanate. Scand J Work Environ Health 1981, 7(4):310-311.

314. Vandenplas O, Cartier A, Lesage J, Cloutier Y, Perreault G, Grammer LC Shaughnessy MA, Malo JL: Prepolymers of hexamethylene diisocyanate as a cause of occupational asthma. J Allergy Clin Immunol 1993, 91(4):850-861.

315. Clarke CW, Aldons PM: Isophorone diisocyanate induced respiratory disease (IPDI). Aust N Z J Med 1981, 11(3):290-292.

316. Kamat SR, Patel MH, Pradhan PV, Taskar SP, Vaidya PR, Kolhatkar VP, Gopalani JP, Chandarana JP, Dalal N, Naik M: Sequential respiratory, psychologic, and immunologic studies in relation to methyl isocyanate exposure over two years with model development. Environ Health Perspect 1992, 97:241-253.

317. Baur X, Chen Z, Marczynski B: Respiratory diseases caused by occupational exposure to 1,5-naphthalene-diisocyanate (NDI): Results of workplacerelated challenge tests and antibody analyses. Am J Ind Med 2001 39(4):369-372.

318. Vijayan VK, Sankaran K: Relationship between lung inflammation, changes in lung function and severity of exposure in victims of the Bhopal tragedy. Eur Respir J 1996, 9(10):1977-1982.

319. Kamat SR, Mahashur AA, Tiwari AK, Potdar PV, Gaur M, Kolhatkar VP, Vaidya P, Parmar D, Rupwate R, Chatterjee TS, et al: Early observations on pulmonary changes and clinical morbidity due to the isocyanate gas leak at Bhopal. J Postgrad Med 1985, 31(2):63-72.

320. Harries MG, Burge PS, Samson M, Taylor AJ, Pepys J: Isocyanate asthma: respiratory symptoms due to 1,5-naphthylene di-isocyanate. Thorax 1979, 34(6):762-766

321. Mehta PS, Mehta AS, Mehta SJ, Makhijani AB: Bhopal tragedy's health effects. A review of methyl isocyanate toxicity. JAMA 1990, 264(21):2781-2787

322. Alexandersson R, Gustafsson P, Hedenstierna G, Rosen G: Exposure to naphthalene-diisocyanate in a rubber plant: symptoms and lung function. Arch Environ Health 1986, 41(2):85-89.

323. Baur X, Wieners D, Marczynski B: Late asthmatic reaction caused by naphthylene-1,5 diisocyanate. Scand J Work Environ Health 2000, 26(1):78-80

324. Fuortes $L$, Kiken S, Makowsky M: An outbreak of naphthalene diisocyanate-induced asthma in a plastics factory. Arch Environ Health 1995, 50(5):337-340

325. Seguin P, Allard A, Cartier A, Malo JL: Prevalence of occupational asthma in spray painters exposed to several types of isocyanates, including polymethylene polyphenylisocyanate. J Occup Med 1987, 29(4):340-344

326. Butcher BT, Jones RN, O'Neil CE, Glindmeyer HW, Diem JE, Dharmarajan V, Weill H, Salvaggio JE: Longitudinal study of workers employed in the manufacture of toluene-diisocyanate. Am Rev Respir Dis 1977, 116(3):411-421.

327. Ott MG, Klees JE, Poche SL: Respiratory health surveillance in a toluene diisocyanate production unit, 1967-97: clinical observations and lung function analyses. Occup Environ Med 2000, 57(1):43-52.

328. Omae K, Higashi T, Nakadate T, Tsugane S, Nakaza M, Sakurai H: Four-year follow-up of effects of toluene diisocyanate exposure on the respiratory system in polyurethane foam manufacturing workers. II. Four-year changes in the effects on the respiratory system. Int Arch Occup Environ Health 1992, 63(8):565-569.

329. Marabini A, Brugnami G, Curradi F, Severini C, Siracusa A: The response to a specific bronchial provocation test and the evolution of occupational asthma. A longitudinal study in subjects with toluene diisocyanateinduced asthma. Med Lav 1994, 85(2):134-141.

330. Karol MH, Tollerud DJ, Campbell TP, Fabbri L, Maestrelli P, Saetta M, Mapp CE: Predictive value of airways hyperresponsiveness and circulating lgE for identifying types of responses to toluene diisocyanate inhalation challenge. Am J Respir Crit Care Med 1994, 149(3 Pt 1):611-615.

331. Paggiaro P, Bacci E, Paoletti $P$, Bernard P, Dente FL, Marchetti G, Talini D, Menconi GF, Giuntini C: Bronchoalveolar lavage and morphology of the airways after cessation of exposure in asthmatic subjects sensitized to toluene diisocyanate. Chest 1990, 98(3):536-542.

332. Axford AT, McKerrow CB, Jones AP, Le Quesne PM: Accidental exposure to isocyanate fumes in a group of firemen. $\mathrm{Br} J$ Ind Med 1976, 33(2):65-71.

333. Vandenplas O, Cartier A, Lesage J, Perrault G, Grammer LC, Malo JL: Occupational asthma caused by a prepolymer but not the monomer of toluene diisocyanate (TDI). J Allergy Clin Immunol 1992, 89(6):1183-1188.

334. Luo JC, Nelsen KG, Fischbein A: Persistent reactive airway dysfunction syndrome after exposure to toluene diisocyanate. Br J Ind Med 1990, 47(4):239-241.

335. Piirila P, Estlander T, Hytonen M, Keskinen H, Tupasela O, Tuppurainen M: Rhinitis caused by ninhydrin develops into occupational asthma. Eur Respir J 1997, 10(8):1918-1921.

336. Buick JB, Todd GR: Concomitant alveolitis and asthma following exposure to triphenylmethane triisocyanate. Occup Med (Lond) 1997, 47(8):504-506.

337. Bourke SJ, Convery RP, Stenton SC, Malcolm RM, Hendrick DJ: Occupational asthma in an isothiazolinone manufacturing plant. Thorax 1997, 52(8):746-748.

338. Burge PS, Richardson MN: Occupational asthma due to indirect exposure to lauryl dimethyl benzyl ammonium chloride used in a floor cleaner. Thorax 1994, 49(8):842-843.

339. Belin L, Wass U, Audunsson G, Mathiasson L: Amines: possible causative agents in the development of bronchial hyperreactivity in workers manufacturing polyurethanes from isocyanates. $\mathrm{Br} J$ Ind Med 1983, 40(3):251-257

340. Estlander T, Kanerva L, Tupasela O, Keskinen H, Jolanki R: Immediate and delayed allergy to nickel with contact urticaria, rhinitis, asthma and contact dermatitis. Clin Exp Allergy 1993, 23(4):306-310

341. Block GT, Yeung M: Asthma induced by nickel. JAMA 1982, 247(11):1600-1602

342. Malo JL, Cartier A, Doepner M, Nieboer E, Evans S, Dolovich J: Occupational asthma caused by nickel sulfate. J Allergy Clin Immunol 1982 69(1 Pt 1):55-59.

343. McConnell LH, Fink JN, Schlueter DP, Schmidt MG Jr: Asthma caused by nickel sensitivity. Ann Intern Med 1973, 78(6):888-890.

344. Thickett KM, McCoach JS, Gerber JM, Sadhra S, Burge PS: Occupational asthma caused by chloramines in indoor swimming-pool air. Eur Respir J 2002, 19(5):827-832.

345. Mehta AJ, Henneberger PK, Toren K, Olin AC: Airflow limitation and changes in pulmonary function among bleachery workers. Eur Respir $J$ 2005, 26(1):133-139.

346. Daenen M, Rogiers P, Van de Walle C, Rochette F, Demedts M, Nemery B: Occupational asthma caused by palladium. Eur Respir J 1999, 13(1):213-216.

347. Silberman DE, Sorrell AH: Allergy in fur workers with special reference to paraphenylenediamine. J Allergy 1959, 30(1):11-18.

348. Moscato G, Pignatti P, Yacoub MR, Romano C, Spezia S, Perfetti L: Occupational asthma and occupational rhinitis in hairdressers. Chest 2005, 128(5):3590-3598.

349. Pankow W, Hein H, Bittner K, Wichert P: Persulfate asthma in hairdressers. Pneumologie 1989, 43(3):173-175.

350. Harth $V$, Raulf-Heimsoth M, Bruning T, Merget R: Isolated late asthmatic reaction after exposure to ammonium persulfate in a hairdresser. Contact Dermatitis 2006, 54(1):62-63.

351. Wrbitzky R, Drexler H, Letzel S: Early reaction type allergies and diseases of the respiratory passages in employees from persulphate production. Int Arch Occup Environ Health 1995, 67(6):413-417. 
352. Therond M, Geraut C, Dupas D, Gayoux C: Pathology des persulfates alcalins: 1989:837-838.

353. Parra FM, Igea JM, Quirce S, Ferrando MC, Martin JA, Losada E: Occupational asthma in a hairdresser caused by persulphate salts. Allergy 1992, 47(6):656-660.

354. Munoz X, Cruz MJ, Orriols R, Bravo C, Espuga M, Morell F: Occupational asthma due to persulfate salts: diagnosis and follow-up. Chest 2003, 123(6):2124-2129.

355. Blainey AD, Ollier S, Cundell D, Smith RE, Davies RJ: Occupational asthma in a hairdressing salon. Thorax 1986, 41(1):42-50.

356. Gamboa PM, de la Cuesta CG, Garcia BE, Castillo JG, Oehling A: Late asthmatic reaction in a hairdresser, due to the inhalation of ammonium persulphate salts. Allergol Immunopathol (Madr) 1989, 17(2):109-111.

357. Baur X, Fruhmann G, von Liebe V: Occupational asthma and dermatitis after exposure to dusts of persulfate salts in two industrial workers (author's transl). Respiration 1979, 38(3):144-150.

358. Kammermeyer JK, Mathews KP: Hypersensitivity to phenylglycine acid chloride. J Allergy Clin Immunol 1973, 52(2):73-84.

359. Wyatt JP, Allister CA: Occupational phosgene poisoning: a case report and review. J Accid Emerg Med 1995, 12(3):212-213.

360. Merget R, Kulzer R, Dierkes-Globisch A, Breitstadt R, Gebler A, Kniffka A, Artelt $S$, Koenig HP, Alt F, Vormberg R, et al: Exposure-effect relationship of platinum salt allergy in a catalyst production plant: conclusions from a 5-year prospective cohort study. J Allergy Clin Immunol 2000 105(2 Pt 1):364-370.

361. Hnizdo E, Esterhuizen TM, Rees D, Lalloo UG: Occupational asthma as identified by the Surveillance of Work-related and Occupational Respiratory Diseases programme in South Africa. Clin Exp Allergy 2001, 31(1):32-39.

362. Merget R, Reineke M, Rueckmann A, Bergmann EM, Schultze-Werninghaus G: Nonspecific and specific bronchial responsiveness in occupational asthma caused by platinum salts after allergen avoidance. Am J Respir Crit Care Med 1994, 150(4):1146-1149.

363. Baker DB, Gann PH, Brooks SM, Gallagher J, Bernstein IL: Cross-sectional study of platinum salts sensitization among precious metals refinery workers. Am J Ind Med 1990, 18(6):653-664.

364. Venables KM, Dally MB, Nunn AJ, Stevens JF, Stephens R, Farrer N, Hunter $J$, Stewart M, Hughes EG, Newman Taylor AJ: Smoking and occupational allergy in workers in a platinum refinery. Bmj 1989, 299(6705):939-942.

365. Pickering CA: Inhalation tests with chemical allergens: complex salts of platinum. Proc R Soc Med 1972, 65(3):272-274.

366. Stenton SC, Kelly CA, Walters EH, Hendrick DJ: Occupational asthma due to a repair process for polyethylene-coated electrical cables. J Soc Occup Med 1989, 39(1):33-34.

367. Gannon PF, Burge PS, Benfield GF: Occupational asthma due to polyethylene shrink wrapping (paper wrapper's asthma). Thorax 1992, 47(9):759.

368. Skerfving S, Akesson B, Simonsson BG: "Meat wrappers' asthma" caused by thermal degradation products of polyethylene. Lancet 1980, 1(8161):211.

369. Kennes B, Garcia-Herreros P, Dierckx P: Asthma from plexiglas powders. Clin Allergy 1981, 11(1):49-54

370. Atis S, Tutluoglu B, Levent E, Ozturk C, Tunaci A, Sahin K, Saral A, Oktay I, Kanik A, Nemery B: The respiratory effects of occupational polypropylene flock exposure. Eur Respir J 2005, 25(1):110-117.

371. Malo JL, Cartier A, Boulet LP, L'Archeveque J, Saint-Denis F, Bherer L, Courteau JP: Bronchial hyperresponsiveness can improve while spirometry plateaus two to three years after repeated exposure to chlorine causing respiratory symptoms. Am J Respir Crit Care Med 1994 150(4):1142-1145.

372. Tuomainen A, Stark H, Seuri M, Hirvonen MR, Linnainmaa M, Sieppi A, Tukiainen $\mathrm{H}$ : Experimental PVC material challenge in subjects with occupational PVC exposure. Environ Health Perspect 2006, 114(9):1409-1413.

373. Lee HS, Ng TP, Ng YL, Phoon WH: Diurnal variation in peak expiratory flow rate among polyvinylchloride compounding workers. $\mathrm{Br} J$ Ind Med 1991, 48(4):275-278.

374. Wegman DH, Smith TJ, Eisen EA, Greaves IA, Fine LJ, Chelton CS: Respiratory effects of work in retail food stores. I. Methodology and exposure assignments. Scand J Work Environ Health 1987, 13(3):203-208.
375. Baser ME, Tockman MS, Kennedy TP: Pulmonary function and respiratory symptoms in polyvinylchloride fabrication workers. Am Rev Respir Dis 1985, 131(2):203-208.

376. Munoz X, Cruz MJ, Albanell M, Morell F: Occupational asthma in food packers. Arch Bronconeumol 2003, 39(7):324-326.

377. Lee HS, Yap J, Wang YT, Lee CS, Tan KT, Poh SC: Occupational asthma due to unheated polyvinylchloride resin dust. $\mathrm{Br} J$ Ind Med 1989, 46(11):820-822.

378. Sokol WN, Aelony Y, Beall GN: Meat-wrapper's asthma. A new syndrome? Jama 1973, 226(6):639-641.

379. Bright P, Burge PS, O'Hickey SP, Gannon PF, Robertson AS, Boran A: Occupational asthma due to chrome and nickel electroplating. Thorax 1997, 52(1):28-32.

380. Hjortsberg U, Nise G, Orbaek P, Soes-Petersen U, Arborelius M Jr: Bronchial asthma due to exposure to potassium aluminumtetrafluoride. Scand J Work Environ Health 1986, 12(3):223.

381. Burge PS, Edge G, Hawkins R, White V, Taylor AJ: Occupational asthma in a factory making flux-cored solder containing colophony. Thorax 1981, 36(11):828-834.

382. Burge PS, Harries MG, O'Brien I, Pepys J: Bronchial provocation studies in workers exposed to the fumes of electronic soldering fluxes. Clin Allergy 1980, 10(2):137-149.

383. Maestrelli P, Alessandri MV, Dal Vecchio L, Bartolucci GB, Cocheo V: Occupational asthma due to colophony. Med Lav 1985, 76(5):371-378.

384. Weiss JS: Reactive airway dysfunction syndrome due to sodium azide inhalation. Int Arch Occup Environ Health 1996, 68(6):469-471.

385. Stenton SC, Dennis JH, Walters EH, Hendrick DJ: Asthmagenic properties of a newly developed detergent ingredient: sodium iso-nonanoyl oxybenzene sulphonate. Br J Ind Med 1990, 47(6):405-410.

386. Hendrick DJ, Connolly MJ, Stenton SC, Bird AG, Winterton IS, Walters EH: Occupational asthma due to sodium iso-nonanoyl oxybenzene sulphonate, a newly developed detergent ingredient. Thorax 1988, 43(6):501-502

387. Ferguson $H$, Thomas KE, Ollier S, Davies RJ: Bronchial provocation testing of sodium iso-nonanoyl oxybenzene sulphonate. Hum Exp Toxicol 1990, 9(2):83-89.

388. Merget $\mathrm{R}$, Korn M: Metabisulphite-induced occupational asthma in a radiographer. Eur Respir J 2005, 25(2):386-388.

389. Madsen J, Sherson D, Kjoller H, Hansen I, Rasmussen K: Occupational asthma caused by sodium disulphite in Norwegian lobster fishing. Occup Environ Med 2004, 61(10):873-874

390. Malo JL, Cartier A, Desjardins A: Occupational asthma caused by dry metabisulphite. Thorax 1995, 50(5):585-586. discussion 589.

391. Pougnet R, Lodde B, Lucas D, Jegaden D, Bell S, Dewitte JD: A case of occupational asthma from metabisulphite in a fisherman. Int Marit Health 2010, 62(3):180-184.

392. Steiner M, Scaife A, Semple S, Hulks G, Ayres JG: Sodium metabisulphite induced airways disease in the fishing and fish-processing industry. Occup Med (Lond) 2008, 58(8):545-550.

393. Hayes JP, Lambourn L, Hopkirk JA, Durham SR, Taylor AJ: Occupational asthma due to styrene. Thorax 1991, 46(5):396-397.

394. Moscato G, Biscaldi G, Cottica D, Pugliese F, Candura S, Candura F: Occupational asthma due to styrene: two case reports. J Occup Med 1987, 29(12):957-960.

395. Andersson E, Knutsson A, Hagberg S, Nilsson T, Karlsson B, Alfredsson L, Toren $\mathrm{K}$ : Incidence of asthma among workers exposed to sulphur dioxide and other irritant gases. Eur Respir J 2006, 27(4):720-725.

396. Koksal N, Hasanoglu HC, Gokirmak M, Yildirim Z, Gultek A: Apricot sulfurization: an occupation that induces an asthma-like syndrome in agricultural environments. Am J Ind Med 2003, 43(4):447-453.

397. Harkonen $H$, Nordman $H$, Korhonen O, Winblad I: Long-term effects of exposure to sulfur dioxide. Lung function four years after a pyrite dust explosion. Am Rev Respir Dis 1983, 128(5):890-893.

398. Rosberg M: Asthma bronchiale caused by sulfthiazole. Acta Medica Scandinavica 1946, 126:185-190.

399. Eriksson KA, Levin JO, Sandstrom T, Lindstrom-Espeling K, Linden G, Stjernberg NL: Terpene exposure and respiratory effects among workers in Swedish joinery shops. Scand J Work Environ Health 1997, 23(2):114-120.

400. Seaton A, Cherrie B, Turnbull J: Rubber glove asthma. Br Med J (Clin Res Ed) 1988, 296(6621):531-532 
401. Honda I, Kohrogi H, Ando M, Araki S, Ueno T, Futatsuka M, Ueda A: Occupational asthma induced by the fungicide tetrachloroisophthalonitrile. Thorax 1992, 47(9):760-761.

402. Baur X, Bittner C: Occupational obstructive airway diseases caused by the natural gas odorant tetrahydrothiophene-two case reports. Am J Ind Med 2009, 52(12):982-986.

403. Vandenplas O, Delwiche JP, Auverdin J, Caroyer UM, Cangh FB: Asthma to tetramethrin. Allergy 2000, 55(4):417-418.

404. Shelton D, Urch B, Tarlo SM: Occupational asthma induced by a carpet fungicide-tributyl tin oxide. J Allergy Clin Immunol 1992, 90(2):274-275.

405. Bruckner HC: Extrinsic asthma in a tungsten carbide worker. J Occup Med 1967, 9(10):518-519.

406. Lee HS, Wang YT, Yeo CT, Tan KT, Ratnam KV: Occupational asthma due to tylosin tartrate. Br J Ind Med 1989, 46(7):498-499.

407. Frigas E, Filley W, Reed CE: Asthma induced by dust from ureaformaldehyde foam insulating material. Chest 1981, 79(6):706-707.

408. Bertrand JP, Simon V, Chau N: Associations of symptoms related to isocyanate, ureaformol, and formophenolic exposures with respiratory symptoms and lung function in coal miners. Int J Occup Environ Health 2007, 13(2):181-187.

409. Irsigler GB, Visser PJ, Spangenberg PA: Asthma and chemical bronchitis in vanadium plant workers. Am J Ind Med 1999, 35(4):366-374.

410. Pistelli R, Pupp N, Forastiere F, Agabiti N, Corbo GM, Tidei F, Perucci CA: Increase of nonspecific bronchial reactivity after occupational exposure to vanadium. Med Lav 1991, 82(3):270-275.

411. Kielkowski D, Rees D: Report on exposure and health, assessment of vanadium workers; 1997.

412. Musk AW, Tees JG: Asthma caused by occupational exposure to vanadium compounds. Med J Aust 1982, 1(4):183-184.

413. Malo $\mathrm{J}$, Cartier A: Occupational asthma due to fumes of galvanized metal. Chest 1987, 92(2):375-377.

414. Malo JL, Cartier A, Dolovich J: Occupational asthma due to zinc. Eur Respir J 1993, 6(3):447-450

415. Kawane $H$, Soejima R, Umeki S, Niki Y: Metal fume fever and asthma. Chest 1988, 93(5):1116-1117.

416. Hambrook DW, Fink JN: Airbag asthma: a case report and review of the literature. Ann Allergy Asthma Immunol 2006, 96(2):369-372.

417. Yang CY, Huang CC, Chiu HF, Chiu JF, Lan SJ, Ko YC: Effects of occupational dust exposure on the respiratory health of Portland cement workers. J Toxicol Environ Health 1996,

49(6):581-588

418. Abrons HL, Petersen MR, Sanderson WT, Engelberg AL, Harber $P$ Symptoms, ventilatory function, and environmental exposures in Portland cement workers. Br J Ind Med 1988, 45(6):368-375

419. Fell AK, Thomassen TR, Kristensen P, Egeland T, Kongerud J: Respiratory symptoms and ventilatory function in workers exposed to portland cement dust. J Occup Environ Med 2003, 45(9):1008-1014.

420. Al-Neaimi Yl, Gomes J, Lloyd OL: Respiratory illnesses and ventilatory function among workers at a cement factory in a rapidly developing country. Occup Med (Lond) 2001, 51(6):367-373.

421. Ali BA, Ballal SG, Albar AA, Ahmed HO: Post-shift changes in pulmonary function in a cement factory in eastern Saudi Arabia. Occup Med (Lond) 1998, 48(8):519-522.

422. Kalacic I: Chronic nonspecific lung disease in cement workers. Arch Environ Health 1973, 26(2):78-83.

423. Mengesha YA, Bekele A: Relative chronic effects of different occupational dusts on respiratory indices and health of workers in three Ethiopian factories. Am J Ind Med 1998, 34(4):373-380.

424. Lockman LE: Case report: allergic contact dermatitis and new-onset asthma. Chromium exposure during leather tanning. Can Fam Physician 2002, 48:1907-1909.

425. De Raeve H, Vandecasteele C, Demedts M, Nemery B: Dermal and respiratory sensitization to chromate in a cement floorer. Am J Ind Med 1998, 34(2):169-176.

426. Shirakawa T, Morimoto $\mathrm{K}$ : Brief reversible bronchospasm resulting from bichromate exposure. Arch Environ Health 1996, 51(3):221-226.

427. Nordby KC, Fell AK, Noto H, Eduard W, Skogstad M, Thomassen Y, Bergamaschi A, Kongerud J, Kjuus H: Exposure to thoracic dust, airway symptoms and lung function in cement production workers. Eur Respir $J$ 2011, 38(6):1278-1286.
428. Piirila P, Espo T, Pfaffli P, Riihimaki V, Wolff H, Nordman H: Prolonged respiratory symptoms caused by thermal degradation products of freons. Scand J Work Environ Health 2003, 29(1):71-77.

429. Lee J, Lee C, Kim CH: Uncontrolled occupational exposure to 1,1-dichloro1-Fluoroethane (HCFC-141b) is associated with acute pulmonary toxicity. Chest 2009, 135(1):149-155.

430. Mirabelli MC, Zock JP, Plana E, Anto JM, Benke G, Blanc PD, DahlmanHoglund A, Jarvis DL, Kromhout $H$, Lillienberg L, et al: Occupational risk factors for asthma among nurses and related healthcare professionals in an international study. Occup Environ Med 2007, 64(7):474-479.

431. Rosenman KD, Reilly MJ, Schill DP, Valiante D, Flattery J, Harrison R, Reinisch F, Pechter E, Davis L, Tumpowsky CM, et al: Cleaning products and work-related asthma. J Occup Environ Med 2003 45(5):556-563

432. Tabar Al, Alvarez MJ, Acero S, Olaguibel JM, Garcia BE, Quirce S: Reactive airways dysfunction syndrome: two case reports. J Investig Allergo/ Clin Immunol 1998, 8(2):119-122.

433. Vizcaya D, Mirabelli MC, Anto JM, Orriols R, Burgos F, Arjona L, Zock JP: A workforce-based study of occupational exposures and asthma symptoms in cleaning workers. Occup Environ Med 2011, 68(12):914-919.

434. Murphy DM, Fairman RP, Lapp NL, Morgan WK: Severe airway disease due to inhalation of fumes from cleansing agents. Chest 1976, 69(3):372-376.

435. Mapp CE, Beghe B, Balboni A, Zamorani G, Padoan M, Jovine L, Baricordi OR, Fabbri LM: Association between HLA genes and susceptibility to toluene diisocyanate-induced asthma. Clin Exp Allergy 2000, 30(5):651-656.

436. Jones RN, Hughes JM, Lehrer SB, Butcher BT, Glindmeyer HW, Diem JE, Hammad YY, Salvaggio J, Weill H: Lung function consequences of exposure and hypersensitivity in workers who process green coffee beans. Am Rev Respir Dis 1982, 125(2):199-202.

437. Zuskin E, Kanceljak B, Skuric Z, Butkovic D: Bronchial reactivity in green coffee exposure. $\mathrm{Br} J$ Ind Med 1985, 42(6):415-420.

438. Lemiere C, Malo JL, McCants M, Lehrer S: Occupational asthma caused by roasted coffee: immunologic evidence that roasted coffee contains the same antigens as green coffee, but at a lower concentration. J Allergy Clin Immunol 1996, 98(2):464-466.

439. Johansen JP, Viskum S: Asthma associated with the handling of green coffee beans. Ugeskr Laeger 1987, 149(42):2853.

440. Oldenburg M, Bittner C, Baur X: Health risks due to coffee dust. Chest 2009, 136(2):536-544

441. Christiani DC, Wang XR, Pan LD, Zhang HX, Sun BX, Dai H, Eisen EA, Wegman DH, Olenchock SA: Longitudinal changes in pulmonary function and respiratory symptoms in cotton textile workers. A 15-yr follow-up study. Am J Respir Crit Care Med 2001, 163(4):847-853.

442. Latza U, Oldenburg M, Baur X: Endotoxin exposure and respiratory symptoms in the cotton textile industry. Arch Environ Health 2004, 59(10):519-525.

443. Oldenburg M, Latza $U$, Baur X: Exposure-response relationship between endotoxin exposure and lung function impairment in cotton textile workers. Int Arch Occup Environ Health 2007, 80(5):388-395.

444. Hayes GB, Ye TT, Lu PL, Dai HL, Christiani DC: Respiratory disease in cotton textile workers: epidemiologic assessment of small airway function. Environ Res 1994, 66(1):31-43

445. Wang XR, Pan LD, Zhang HX, Sun BX, Dai HL, Christiani DC: A longitudinal observation of early pulmonary responses to cotton dust. Occup Environ Med 2003, 60(2):115-121.

446. Li D, Zhong YN, Rylander R, Ma QY, Zhou XY: Longitudinal study of the health of cotton workers. Occup Environ Med 1995, 52(5):328-331.

447. Mberikunashe J, Banda S, Chadambuka A, Gombe NT, Shambira G, Tshimanga M, Matchaba-Hove R: Prevalence and risk factors for obstructive respiratory conditions among textile industry workers in Zimbabwe, 2006. Pan Afr Med J 2010, 6:1

448. Hendy MS, Beattie BE, Burge PS: Occupational asthma due to an emulsified oil mist. Br J Ind Med 1985, 42(1):51-54.

449. Keskinen $H$, Nordman $H$, Terho EO: ECG ink as a cause of asthma. Allergy 1981, 36(4):275-276

450. Rodenstein D, Stanescu DC: Bronchial asthma following exposure to ECG ink. Ann Allergy 1982, 48(6):351-352.

451. Milton DK, Wypij D, Kriebel D, Walters MD, Hammond SK, Evans JS Endotoxin exposure-response in a fiberglass manufacturing facility. Am J Ind Med 1996, 29(1):3-13. 
452. Jaakkola JJ, Piipari R, Jaakkola MS: Occupation and asthma: a populationbased incident case-control study. Am J Epidemio/ 2003, 158(10):981-987.

453. Lambourn EM, Hayes JP, McAllister WA, Taylor AJ: Occupational asthma due to EPO 60. Br J Ind Med 1992, 49(4):294-295.

454. Cockcroft DW, Cartier A, Jones G, Tarlo SM, Dolovich J, Hargreave FE: Asthma caused by occupational exposure to a furan-based binder system. J Allergy Clin Immunol 1980, 66(6):458-463.

455. Chan-Yeung M, Schulzer M, MacLean L, Dorken E, Grzybowski S: Epidemiologic health survey of grain elevator workers in British Columbia. Am Rev Respir Dis 1980, 121(2):329-338.

456. Williams N, Skoulas A, Merriman JE: Exposure to Grain Dust. I. a Survey of the Effects. J Occup Med 1964, 6:319-329.

457. Skoulas A, Williams N, Merriman JE: Exposure to Grain Dust. li. a Clinical Study of the Effects. J Occup Med 1964, 6:359-372.

458. Baur X, Preisser A, Wegner R: Asthma due to grain dust. Pneumologie 2003, 57(6):335-339.

459. Chan-Yeung M, Dimich-Ward H, Enarson DA, Kennedy SM: Five crosssectional studies of grain elevator workers. Am J Epidemiol 1992, 136(10):1269-1279.

460. Ye TT, Huang JX, Shen YE, Lu PL, Christiani DC: Respiratory symptoms and pulmonary function among Chinese rice-granary workers. Int J Occup Environ Health 1998, 4(3):155-159.

461. Dube D, Puruckherr M, Byrd RP Jr, Roy TM: Reactive airways dysfunction syndrome following metal fume fever. Tenn Med 2002, 95(6):236-238.

462. Zacharisen MC, Kadambi AR, Schlueter DP, Kurup VP, Shack JB, Fox JL, Anderson HA, Fink JN: The spectrum of respiratory disease associated with exposure to metal working fluids. J Occup Environ Med 1998, 40(7):640-647.

463. Wieslander G, Janson C, Norback D, Bjornsson E, Stalenheim G, Edling C: Occupational exposure to water-based paints and self-reported asthma, lower airway symptoms, bronchial hyperresponsiveness, and lung function. Int Arch Occup Environ Health 1994 66(4):261-267

464. Temel O, Sakar Coskun A, Yaman N, Sarioglu N, Alkac C, Konyar I, Ozgen Alpaydin A, Celik P, Cengiz Ozyurt B, Keskin E, et al: Occupational asthma in welders and painters. Tuberk Toraks 2010, 58(1):64-70.

465. Baur X, Schneider EM, Wieners D, Czuppon AB: Occupational asthma to perfume. Allergy 1999, 54(12):1334-1335.

466. Lings S: Pesticide lung: a pilot investigation of fruit-growers and farmers during the spraying season. $\mathrm{Br} J$ Ind Med 1982, 39(4):370-376.

467. Boers D, van Amelsvoort L, Colosio C, Corsini E, Fustinoni S, Campo L, Bosetti C, La Vecchia C, Vergieva T, Tarkowski M, et al: Asthmatic symptoms after exposure to ethylenebisdithiocarbamates and other pesticides in the Europit field studies. Hum Exp Toxicol 2008, 27(9):721-727.

468. Ng TP, Lee HS, Malik MA, Chee CB, Cheong TH, Wang YT: Asthma in chemical workers exposed to aliphatic polyamines. Occup Med (Lond) 1995, 45(1):45-48.

469. Cartier A, Vandenplas O, Grammer LC, Shaughnessy MA, Malo JL: Respiratory and systemic reaction following exposure to heated electrostatic polyester paint. Eur Respir J 1994 7(3):608-611.

470. Zuskin E, Mustajbegovic J, Schachter EN, Kern J, Budak A, Godnic-Cvar J: Respiratory findings in synthetic textile workers. Am J Ind Med 1998, 33(3):263-273.

471. Burge PS, Scott JA, McCoach J: Occupational asthma caused by aluminum. Allergy 2000, 55(8):779-780.

472. Chan-Yeung M, Wong R, MacLean L, Tan F, Schulzer M, Enarson D, Martin A, Dennis R, Grzybowski S: Epidemiologic health study of workers in an aluminum smelter in British Columbia. Effects on the respiratory system. Am Rev Respir Dis 1983, 127(4):465-469.

473. Desjardins A, Bergeron JP, Ghezzo H, Cartier A, Malo JL: Aluminium potroom asthma confirmed by monitoring of forced expiratory volume in one second. Am J Respir Crit Care Med 1994, 150(6 Pt 1):1714-1717.

474. Musk AW, de Klerk NH, Beach JR, Fritschi L, Sim MR, Benke G, Abramson M, McNeil JJ: Respiratory symptoms and lung function in alumina refinery employees. Occup Environ Med 2000, 57(4):279-283.

475. O'Donnell TV, Welford B, Coleman ED: Potroom asthma: New Zealand experience and follow-up. Am J Ind Med 1989, 15(1):43-49.

476. Saric M, Godnic-Cvar J, Gomzi M, Stilinovic L: The role of atopy in potroom workers' asthma. Am J Ind Med 1986, 9(3):239-242.
477. Sorgdrager B, de Looff AJ, de Monchy JG, Pal TM, Dubois AE, Rijcken B: Occurrence of occupational asthma in aluminum potroom workers in relation to preventive measures. Int Arch Occup Environ Health 1998, 71:53-59.

478. Sorgdrager B, de Looff AJ, Pal TM, van Dijk FJ, de Monchy JG: Factors affecting FEV1 in workers with potroom asthma after their removal from exposure. Int Arch Occup Environ Health 2001, 74(1):55-58.

479. Blomqvist A, Duzakin-Nystedt M, Ohlson CG, Andersson L, Jonsson B, Nielsen J, Welinder H: Airways symptoms, immunological response and exposure in powder painting. Int Arch Occup Environ Health 2005, 78(2):123-131.

480. Nakano Y, Tsuchiya T, Hirose K, Chida K: Occupational asthma caused by pyrazolone derivative used in silver halide photographic paper. Chest 2000, 118(1):246-248.

481. Alanko K, Keskinen H, Bjorksten F, Ojanen S: Immediate-type hypersensitivity to reactive dyes. Clin Allergy 1978, 8(1):25-31.

482. Nilsson R, Nordlinder R, Wass U, Meding B, Belin L: Asthma, rhinitis, and dermatitis in workers exposed to reactive dyes. $\mathrm{Br} J$ Ind Med 1993, 50(1):65-70.

483. Park HS, Lee MK, Hong CS: Reactive dye induced occupational asthma without nonspecific bronchial hyperreactivity. Yonsei Med J 1990, 31(2):98-102.

484. Park HS, Lee MK, Kim BO, Lee KJ, Roh JH, Moon YH, Hong CS: Clinical and immunologic evaluations of reactive dye-exposed workers. J Allergy Clin Immunol 1991, 87(3):639-649.

485. Romano C, Sulotto F, Pavan I, Chiesa A, Scansetti G: A new case of occupational asthma from reactive dyes with severe anaphylactic response to the specific challenge. Am J Ind Med 1992, 21(2):209-216.

486. Forrester BG: Reactive airways dysfunction syndrome: occurrence after exposure to a refractory ceramic fiber-phosphoric acid binder mixture. South Med J 1997, 90(4):447-450.

487. Lemasters GK, Lockey JE, Levin LS, McKay RT, Rice CH, Horvath EP, Papes DM, Lu JW, Feldman DJ: An industry-wide pulmonary study of men and women manufacturing refractory ceramic fibers. Am J Epidemiol 1998, 148(9):910-919.

488. Almeida AG, Duarte R, Mieiro L, Paiva AC, Rodrigues AM, Almeida MH, Barbara C: Pulmonary function in Portuguese firefighters. Rev Port Pneumol 2007, 13(3):349-364.

489. Moisan TC: Prolonged asthma after smoke inhalation: a report of three cases and a review of previous reports. J Occup Med 1991, 33(4):458-461.

490. Greven F, Krop E, Spithoven J, Rooyackers J, Kerstjens H, Heederik D: Lung function, bronchial hyperresponsiveness, and atopy among firefighters. Scand J Work Environ Health 2011, 37(4):325-331.

491. Kelsall HL, Sim MR, Forbes AB, Glass DC, McKenzie DP, Ikin JF, Abramson MJ, Blizzard L, Ittak P: Symptoms and medical conditions in Australian veterans of the 1991 Gulf War: relation to immunisations and other Gulf War exposures. Occup Environ Med 2004, 61(12):1006-1013.

492. Ekici A, Ekici M, Kurtipek E, Akin A, Arslan M, Kara T, Apaydin Z, Demir S: Obstructive airway diseases in women exposed to biomass smoke. Environ Res 2005, 99(1):93-98.

493. Burge PS, Perks W, O'Brien IM, Hawkins R, Green M: Occupational asthma in an electronics factory. Thorax 1979, 34(1):13-18.

494. Lee HS, Koh D, Chia HP, Phoon WH: Symptoms, lung function, and diurnal variation in peak expiratory flow rate among female solderers in the electronics industry. Am J Ind Med 1994, 26(5):613-619.

495. Stevens JJ: Asthma due to soldering flux: a polyether alcoholpolypropylene glycol mixture. Ann Allergy 1976, 36(6):419-422

496. Cakmak A, Ekici A, Ekici M, Arslan M, Iteginli A, Kurtipek E, Kara T: Respiratory findings in gun factory workers exposed to solvents. Respir Med 2004, 98(1):52-56.

497. Ebbehoj NE, Hein HO, Suadicani P, Gyntelberg F: Occupational organic solvent exposure, smoking, and prevalence of chronic bronchitis-an epidemiological study of 3387 men. J Occup Environ Med 2008, 50(7):730-735.

498. Tarlo SM: Occupational asthma induced by tall oil in the rubber tyre industry. Clin Exp Allergy 1992, 22(1):99-101. 
499. Bayeux-Dunglas MC, Deparis P, Touati MA, Ameille J: Occupational asthma in a teacher after repeated exposure to tear gas. Rev Mal Respir 1999, 16(4):558-559.

500. Hill AR, Silverberg NB, Mayorga D, Baldwin HE: Medical hazards of the tear gas CS. A case of persistent, multisystem, hypersensitivity reaction and review of the literature. Medicine (Baltimore) 2000, 79(4):234-240.

501. Hu H, Christiani D: Reactive airways dysfunction after exposure to teargas. Lancet 1992, 339(8808):1535.

502. Roth VS, Franzblau A: RADS after exposure to a riot-control agent: a case report. J Occup Environ Med 1996, 38(9):863-865.

503. El-Zein M, Malo JL, Infante-Rivard C, Gautrin D: Incidence of probable occupational asthma and changes in airway calibre and responsiveness in apprentice welders. Eur Respir J 2003, 22(3):513-518.

504. Jafari AJ, Assari MJ: Respiratory effects from work-related exposure to welding fumes in Hamadan, Iran. Arch Environ Health 2004, 59(3):116-120.

505. Nakadate $T$, Aizawa $Y$, Yagami T, Zheg YQ, Kotani M, Ishiwata $K$ : Change in obstructive pulmonary function as a result of cumulative exposure to welding fumes as determined by magnetopneumography in Japanese arc welders. Occup Environ Med 1998, 55(10):673-677.

506. Beach JR, Dennis JH, Avery AJ, Bromly CL, Ward RJ, Walters EH, Stenton SC, Hendrick DJ: An epidemiologic investigation of asthma in welders. Am J Respir Crit Care Med 1996, 154(5):1394-1400.

507. Hannu T, Piipari R, Toskala E: Immediate hypersensitivity type of occupational laryngitis in a welder exposed to welding fumes of stainless steel. Am J Ind Med 2006, 49(5):402-405.

508. Karjalainen A, Martikainen R, Oksa P, Saarinen K, Uitti J: Incidence of asthma among Finnish construction workers. J Occup Environ Med 2002, 44(8):752-757

509. Contreras GR, Chan-Yeung M: Bronchial reactions to exposure to welding fumes. Occup Environ Med 1997, 54(11):836-839.

510. Hannu T, Piipari R, Kasurinen H, Keskinen H, Tuppurainen M, Tuomi T: Occupational asthma due to manual metal-arc welding of special stainless steels. Eur Respir J 2005, 26(4):736-739.

511. Vandenplas O, Delwiche JP, Vanbilsen ML, Joly J, Roosels D: Occupational asthma caused by aluminium welding. Eur Respir J 1998, 11(5):1182-1184.

512. Vandenplas O, Dargent F, Auverdin JJ, Boulanger J, Bossiroy JM, Roosels D, Van de Weyer R: Occupational asthma due to gas metal arc welding on mild steel. Thorax 1995, 50(5):587-588. discussion 589.

513. Keskinen $H$, Kalliomaki $\mathrm{PL}$, Alanko K: Occupational asthma due to stainless steel welding fumes. Clin Allergy 1980, 10(2):151-159.

514. Halvani GH, Zare M, Halvani A, Barkhordari A: Evaluation and comparison of respiratory symptoms and lung capacities in tile and ceramic factory workers of Yazd. Arh Hig Rada Toksikol 2008, 59(3):197-204.

515. Neghab M, Zadeh JH, Fakoorziba MR: Respiratory toxicity of raw materials used in ceramic production. Ind Health 2009, 47(1):64-69.

516. Oliver LC, Miracle-McMahill H, Littman AB, Oakes JM, Gaita RR Jr: Respiratory symptoms and lung function in workers in heavy and highway construction: a cross-sectional study. Am J Ind Med 2001, 40(1):73-86.

517. Kaukiainen A, Martikainen R, Riala R, Reijula K, Tammilehto L: Work tasks, chemical exposure and respiratory health in construction painting. Am J Ind Med 2008, 51(1):1-8.

518. Walusiak J, Krawczyk-Adamus P, Hanke W, Wittczak T, Palczynski C: Small nonspecialized farming as a protective factor against immediate-type occupational respiratory allergy? Allergy 2004,

59(12):1294-1300.

519. Gomez MI, Hwang SA, Lin S, Stark AD, May JJ, Hallman EM: Prevalence and predictors of respiratory symptoms among New York farmers and farm residents. Am J Ind Med 2004, 46(1):42-54

520. Dosman JA, Graham BL, Hall D, Van Loon P, Bhasin P, Froh F: Respiratory symptoms and pulmonary function in farmers. J Occup Med 1987, 29(1):38-43.

521. Rask-Andersen A: Asthma increase among farmers: a 12-year follow-up. Ups J Med Sci 2011, 116(1):60-71.

522. Portengen L, Preller L, Tielen M, Doekes G, Heederik D: Endotoxin exposure and atopic sensitization in adult pig farmers. J Allergy Clin Immunol 2005, 115(4):797-802.

523. Monso E, Riu E, Radon K, Magarolas R, Danuser B, Iversen M, Morera J, Nowak D: Chronic obstructive pulmonary disease in never-smoking animal farmers working inside confinement buildings. Am J Ind Med 2004, 46(4):357-362.
524. Radon K, Weber C, Iversen M, Danuser B, Pedersen S, Nowak D: Exposure assessment and lung function in pig and poultry farmers. Occup Environ Med 2001, 58(6):405-410.

525. Hansen ES: A cohort mortality study of foundry workers. Am J Ind Med 1997, 32(3):223-233.

526. Hahn R, Beck B: Incidence of chronic bronchitis in foundry workers. Z Erkr Atmungsorgane 1986, 166(3):267-273.

527. Pechter E, Davis LK, Tumpowsky C, Flattery J, Harrison R, Reinisch F, Reilly MJ, Rosenman KD, Schill DP, Valiante D, et al: Work-related asthma among health care workers: surveillance data from California, Massachusetts, Michigan, and New Jersey, 1993-1997. Am J Ind Med 2005, 47(3):265-275.

528. Arif AA, Delclos GL: Association between cleaning-related chemicals and work-related asthma and asthma symptoms among healthcare professionals. Occup Environ Med 2012, 69(1):35-40.

529. Arif AA, Delclos GL, Serra C: Occupational exposures and asthma among nursing professionals. Occup Environ Med 2009, 66(4):274-278

530. Bala S, Tabaku A: Chronic obstructive pulmonary disease in iron-steel and ferrochrome industry workers. Cent Eur J Public Health 2010, 18(2):93-98.

531. Rylander R, Carvalheiro MF: Airways inflammation among workers in poultry houses. Int Arch Occup Environ Health 2006, 79(6):487-490

532. Hagmar L, Schutz A, Hallberg T, Sjoholm A: Health effects of exposure to endotoxins and organic dust in poultry slaughter-house workers. Int Arch Occup Environ Health 1990, 62(2):159-164.

533. Danuser B, Wyss C, Hauser R, von Planta U, Folsch D: Lung function and symptoms in employees of poultry farms]. Soz Praventivmed 1988, 33(6):286-291.

534. King BS, Page EH, Mueller CA, Dollberg DD, Gomez KE, Warren AM: Eye and respiratory symptoms in poultry processing workers exposed to chlorine by-products. Am J Ind Med 2006, 49(2):119-126.

535. Borghetti C, Magarolas R, Badorrey I, Radon K, Morera J, Monso E: Sensitization and occupational asthma in poultry workers]. Med Clin (Barc) 2002, 118(7):251-255.

536. Perfetti L, Cartier A, Malo JL: Occupational asthma in poultryslaughterhouse workers. Allergy 1997, 52(5):594-595.

537. Vogelzang PF, van der Gulden JW, Folgering H, Heederik D, Tielen MJ, van Schayck CP: Longitudinal changes in bronchial responsiveness associated with swine confinement dust exposure. Chest 2000 117(5):1488-1495.

538. Reynolds SJ, Donham KJ, Whitten P, Merchant JA, Burmeister LF, Popendorf WJ: Longitudinal evaluation of dose-response relationships for environmental exposures and pulmonary function in swine production workers. Am J Ind Med 1996, 29(1):33-40.

539. Schwartz DA, Donham KJ, Olenchock SA, Popendorf WJ, Van Fossen DS, Burmeister LF, Merchant JA: Determinants of longitudinal changes in spirometric function among swine confinement operators and farmers. Am J Respir Crit Care Med 1995, 151(1):47-53.

540. Vogelzang PF, van der Gulden JW, Folgering $H$, Kolk JJ, Heederik D, Preller L, Tielen MJ, van Schayck CP: Endotoxin exposure as a major determinant of lung function decline in pig farmers. Am J Respir Crit Care Med 1998, 157(1):15-18.

541. Banauch Gl, Alleyne D, Sanchez R, Olender K, Cohen HW, Weiden M, Kelly KJ, Prezant DJ: Persistent hyperreactivity and reactive airway dysfunction in firefighters at the World Trade Center. Am J Respir Crit Care Med 2003, 168(1):54-62.

542. Banauch Gl, Dhala A, Prezant DJ: Pulmonary disease in rescue workers at the World Trade Center site. Curr Opin Pulm Med 2005, 11(2):160-168

543. Banauch Gl, Hall C, Weiden M, Cohen HW, Aldrich TK, Christodoulou V, Arcentales N, Kelly KJ, Prezant DJ: Pulmonary function after exposure to the World Trade Center collapse in the New York City Fire Department. Am J Respir Crit Care Med 2006, 174(3):312-319.

544. Herbstman JB, Frank R, Schwab M, Williams DL, Samet JM, Breysse PN Geyh AS: Respiratory effects of inhalation exposure among workers during the clean-up effort at the World Trade Center disaster site. Environ Res 2005, 99(1):85-92.

545. Salzman SH, Moosavy FM, Miskoff JA, Friedmann P, Fried G, Rosen MJ: Early respiratory abnormalities in emergency services police officers 
at the World Trade Center site. J Occup Environ Med 2004, 46(2):113-122

546. Mauer MP, Cummings KR, Hoen R: Long-term respiratory symptoms in World Trade Center responders. Occup Med (Lond) 2010, 60(2):145-151

547. Feinstein AR, Horwitz Rl: Problems in the "evidence" of "evidence-based medicine". Am J Med 1997, 103(6):529-535.

548. Miettinen OS: Evidence in medicine: invited commentary. Cmaj 1998, 158(2):215-221.

549. Miettinen OS: Evidence-based medicine, case-based medicine; scientific medicine, quasi-scientific medicine. Commentary on Tonelli (2006), Integrating evidence into clinical practice: an alternative to evidencebased approaches. Journal of Evaluation in Clinical Practice 12, 248-256. J Eval Clin Pract 2006, 12(3):260-264.

550. Tobin MJ: Counterpoint: evidence-based medicine lacks a sound scientific base. Chest 2008, 133(5):1071-1074. discussion 1074-1077.

551. Lijmer JG, Mol BW, Heisterkamp S, Bonsel GJ, Prins MH, van der Meulen JH, Bossuyt PM: Empirical evidence of design-related bias in studies of diagnostic tests. Jama 1999, 282(11):1061-1066.

552. Beach J, Rowe BH, Blitz S, Crumley E, Hooton N, Russell K, Spooner C, Klassen T: Diagnosis and management of work-related asthma. Evidence Report/Technology Assessment No 129. Rockville: U.S. Department of Health and Human Services, Agency for Healthcare Research and Quality; 2005. http://www.ahrq.gov/downloads/pub/evidence/pdf/asthmawork/ asthwork.pdf.

553. Kunz R, Burnand B, Schunemann HJ: The GRADE System. An international approach to standardize the graduation of evidence and recommendations in guidelines. Internist (Berl) 2008, 49(6):673-680

554. West S, King V, CT S, Lohr KN, McKoy N, Sutton SF, Lux L: Systems to rate the strength of scientific evidence, vol. 47. Rockville: Agency for Healthcare, Research and Quality; 2002. http://archive.ahrq.gov/clinic/tp/strengthtp.htm.

555. Quint J, Beckett WS, Campleman SL, Sutton P, Prudhomme J, Flattery J, Harrison R, Cowan B, Kreutzer R: Primary prevention of occupational asthma: identifying and controlling exposures to asthma-causing agents. Am J Ind Med 2008, 51(7):477-491.

556. AbuDhaise BA, Rabi AZ, Al Zwairy MA, El Hader AF, El Qaderi S: Pulmonary manifestations in cement workers in Jordan. Int $J$ Occup Med Environ Health 1997, 10(4):417-428.

557. Salvi SS, Barnes PJ: Chronic obstructive pulmonary disease in nonsmokers. Lancet 2009, 374(9691):733-743.

558. Blanc FX, Coirault C, Oliviero P, Lecarpentier Y: Relaxation of tracheal smooth muscle is impaired in innate airway hyperresponsiveness. Eur Respir J 2009, 34(2):417-424.

559. Balmes JR, Nowak D: COPD caused by occupational exposure. In COPD. Edited by Donner CF, Carone M. Oxford: Clinical publishing: 2007:85-95.

560. Blanc PD, Toren K: Occupation in chronic obstructive pulmonary disease and chronic bronchitis: an update. Int J Tuberc Lung Dis 2007, 11(3):251-257

561. Toren K, Balmes J: Chronic obstructive pulmonary disease: does occupation matter? Am J Respir Crit Care Med 2007, 176(10):951-952

562. Bardana EJ Jr: Reactive airways dysfunction syndrome (RADS): guidelines for diagnosis and treatment and insight into likely prognosis. Ann Allergy Asthma Immunol 1999, 83(6 Pt 2):583-586.

563. Vandenplas O, Malo JL: Definitions and types of work-related asthma: a nosological approach. Eur Respir 」 2003, 21(4):706-712

564. Blanc PD, Menezes AM, Plana E, Mannino DM, Hallal PC, Toren K, Eisner MD, Zock JP: Occupational exposures and COPD: an ecological analysis of international data. Eur Respir J 2009, 33(2):298-304.

565. Malo JL, Chan-Yeung M: Agents causing occupational asthma. J Allergy Clin Immunol 2009, 123(3):545-550.

566. Cullinan P: Irritant-induced asthma from work. What happens next? Am J Respir Crit Care Med 2009, 179(10):857-858.

567. Tarlo SM, Boulet LP, Cartier A, Cockcroft D, Cote J, Hargreave FE, Holness L, Liss G, Malo JL, Chan-Yeung M: Canadian Thoracic Society guidelines for occupational asthma. Can Respir J 1998, 5(4):289-300.
568. Ernst P, Fitzgerald JM, Spier S: Canadian Asthma Consensus Conference Summary of recommendations. Can Respir J 1996 3(2):89-101.

569. Newman Taylor AJ, Cullinan P, Burge PS, Nicholson P, Boyle C: BOHRF guidelines for occupational asthma. Thorax 2005, 60(5):364-366

570. Heederik D, van Rooy F: Exposure assessment should be integrated in studies on the prevention and management of occupational asthma. Occup Environ Med 2008, 65(3):149-150.

571. Venables KM: Prevention of occupational asthma. Eur Respir J 1994, 7(4):768-778.

572. Vineis P: Evidence-based primary prevention? Scand I Work Environ Health 2000, 26(5):443-448.

573. Drummond MF, Stoddart GL, Torrance GW: Method of economic evaluation of health care programes. Oxford: Oxford Medical Publications; 1987.

574. Heederik D, Henneberger PK, Redlich CA: Primary prevention: exposure reduction, skin exposure and respiratory protection. Eur Respir Rev 2012 21(124):112-124.

575. Schoenbach V, Wayne D: Understanding the fundamentals of epidemiology: an evolving text. Chapter 8: Analytic study designs. Chapel Hill: epidemiolog. net; 2000. http://www.epidemiolog.net/evolving/TableOfContents.htm.

doi:10.1186/1745-6673-7-19

Cite this article as: Baur et al:: Bronchial asthma and COPD due to irritants in the workplace - an evidence-based approach. Journal of Occupational Medicine and Toxicology 2012 7:19.

\section{Submit your next manuscript to BioMed Central and take full advantage of:}

- Convenient online submission

- Thorough peer review

- No space constraints or color figure charges

- Immediate publication on acceptance

- Inclusion in PubMed, CAS, Scopus and Google Scholar

- Research which is freely available for redistribution 